Ecology, 1994, v.75, n.2, pp.532-547

ISSN: 0012-9658

DOI: $10.2307 / 1939556$

http://www.esajournals.org/loi/ecol?cookieSet=1

http://www.esajournals.org/doi/abs/10.2307/1939556

(C)1994 by the Ecological Society of America 


\title{
ASSESSING HOW FISH PREDATION AND INTERSPECIFIC PREY COMPETITION INFLUENCE A CRAYFISH ASSEMBLAGE ${ }^{1}$
}

\author{
James E. Garvey, Roy A. Stein, and Heather M. Thomas \\ Aquatic Ecology Laboratory, Department of Zoology, The Ohio State University, Columbus, Ohio 43212 USA
}

Abstract. In northern Wisconsin lakes, the introduced crayfish Orconectes rusticus is replacing $O$. propinquus, a previous invader, and $O$. virilis, a native crayfish. Herein, we explore how fish predation and competition interact to drive this change in crayfish species composition. In outside pools, we conducted selective predation experiments exposing crayfish to largemouth bass, Micropterus salmoides, to quantify patterns of crayfish vulnerability. To determine how interactions among crayfish influence susceptibility, we quantified shelter use and behavioral interactions among crayfish in aquaria and outside pools.

At equal size, $O$. virilis was more susceptible to fish predation than either of the invaders, $O$. rusticus and $O$. propinquus; the two invaders were equally susceptible to predation. However, sizes of these crayfish in the field are $O$. virilis $>O$. rusticus $>O$. propinquus. Because fish predators prefer small crayfish, at unequal size, small $O$. propinquus were more vulnerable to predation than large $O$. rusticus. Thus, $O$. rusticus can replace $O$. propinquus due to natural size differences. Although $O$. virilis grows larger than the invaders, it was more susceptible even when $3 \mathrm{~mm}$ larger. We hypothesized that $O$. virilis, although large, participated in behaviors that increased its risk to predation.

When provided with unlimited shelters, all three species increased refuge use under predatory risk. When shelters were limiting and fish present, $O$. virilis was excluded from shelters by invaders. $O$. virilis also participated in risky behaviors, such as increased activity and swimming. Both agonistic interactions with congeners and approaches by largemouth bass increased risky behaviors in $O$. virilis. In addition, $O$. virilis was innately less aggressive than invaders. Given these behaviors, $O$. virilis was consumed at high rates and would be eventually replaced in lakes.

In northern Wisconsin lakes, fish predation and crayfish-crayfish competition interact to influence crayfish replacements. Based on our results, largemouth bass predation modifies the outcome of interference competition among the three crayfishes and, in turn, competitive interactions among the crayfishes influence susceptibility to fish predation. We predict that $O$. virilis should suffer high mortality to fish predation in the presence, rather than in the absence, of the two invading species. Our results support the hypothesis that, in areas of sympatry where predators are selective and prey species compete, predation and competition interact to determine community structure.

Key words: aggression; avoidance behavior; competition; cravfish; habitat use; largemouth bass, Micropterus salmoides; morphology; north temperate lakes; Orconectes propinquus; Orconectes rusticus; Orconectes virilis; predation; refuge use; size; species invasion.

\section{INTRODUCTION}

Ecologists have long sought to understand how biotic forces shape communities. In a vast number of studies, both predation (see Sih et al. 1985, Gliwicz and Pijanowska 1989 for reviews) and competition (Hutchinson 1959. MacArthur and Levins 1967. Price 1978 Smith and Cooper 1982, Morin 1984, Johnson et al. 1985, see Schoener 1983 for review) have been found to dramatically influence community structure. Although these two forces can work independently, they also can act together in complex ways to shape many communities (e.g., Hairston et al. 1960).

Relationships between predation and competition are varied. Selective predators can remove competitively dominant prey and thereby increase prey species

Manuscript received 18 November 1992; revised 6 May 1993: accepted 21 May 1993. diversity (Paine 1966 Inouye et al. 1980, Morin 1981, 1986, Steneck et al. 1991). Predation and competition can vary in importance along environmental gradients (Menge and Sutherland 1976, Lubchenco 1978, Southerland 1986) and among different seasons (Cubit 1984). By reducing prey density, predation can release surviving prey from competition for limited resources (Wilbur et al. 1983). Clearly, predation and competition are interrelated mechanisms that influence community structure.

Predation and competition can interact such that one biotic process modifies the other (Kotler and Holt 1989). Although predation can directly modify competition by removal of competitively dominant prey it also can indirectly influence prey behaviors and, hence, prey resource use (Mittelbach 1981, Werner et al. 1983). Both noncompetitive and competitive interactions among prey can alter the outcome of predation. To our 
knowledge, such relationships have only been demonstrated for noncompeting prey. Noncompetitive interactions between salamanders and isopods modify predatory risk of both species (Huang and Sih 1990, 1991). Similarly, crayfish reduce predatory risk of sculpins by their shared predator (McNeely et al. 1990). Although, for these systems, prey only share a common predator and not common resources, evidence exists that competition for limited resources among sympatric crayfish species does result in modified predation by fish (Butler and Stein 1985, Söderbäck 1990).

Herein, we explore how fish predation and interspecific competition interact to influence a crayfish species replacement. In northern Wisconsin lakes, the crayfish $O$. rusticus, the most recent invader, is replacing $O$. propinquus, a previous invader, and $O$. virilis, a native crayfish (Capelli 1982, Lodge et al. 1986, Olsen et al. 1991). O. propinquus can replace O. virilis (Capelli 1982, Lodge et al. 1986, Olsen et al. 1991). Replacement mechanisms likely include frequency of human introduction, predation, and competitive exclusion (Lodge et al. 1986, Lodge 1993). Replacement rates are relatively rapid and monotonic (Olsen et al. 1991). Such characteristics provide an ideal system in which to explore how predation and competition contribute to changes in species assemblages.

Fish predation, crayfish interactions, and crayfish behavior likely contribute to the replacement. Crayfish are important to fish diets (Saiki and Ziebell 1976, Stein 1977) and, when tethered in the field, crayfish are selectively consumed by fish (Kershner 1992, Mather and Stein 1993, DiDonato and Lodge, in press). Thus, selective predation by fish likely influences crayfish populations. Crayfish interactions and behavior also can influence the replacement by modifying susceptibility to fish predators. Although $O$. rusticus, $O$. propinquus, and $O$. virilis are morphologically similar (Capelli and Capelli 1980), they differ in body (Corey 1988, Olsen et al. 1991) and chela size (Garvey and Stein 1993). These crayfishes also differ in aggressive (Capelli and Munjal 1982) and nonaggressive behaviors and, in the absence of predatory risk, differentially compete for shelter (Capelli and Munjal 1982). Because size, behavior, and refuge use determine vulnerability to predation in crayfish (Stein and Magnuson 1976, Stein 1977), congeneric differences in these characteristics likely influence species-specific susceptibility.

Although many mechanisms likely drive the replacement, we focussed on the roles of predation and competition. To determine how selective predation is mediated through competitive interactions among these three crayfishes and through their differential morphological and behavioral characteristics, we pursued two objectives. First, we quantified selective fish predation among $O$. rusticus, $O$. propinquus, and $O$. virilis. We then explored how crayfish morphology, interference competition, nonaggressive behaviors, and aggression influenced crayfish vulnerability to fish predators. By simultaneously evaluating predation and competition, we assess how these two ecological processes could influence ongoing species replacements in northern Wisconsin lakes.

\section{Methods}

We conducted experiments in 200-L laboratory aquaria (photocycle: $16 \mathrm{~h}$ light $: 8 \mathrm{~h}$ dark) and in circular, outdoor pools ( $1.8 \mathrm{~m}$ diameter, $1 \mathrm{~m}$ depth) at University of Wisconsin, Center for Limnology, Trout Lake Station, Vilas County, Wisconsin, during June through August, 1990 and 1991. To maintain water quality, all pools and aquaria were supplied with continuous flow-through water from the epilimnion of Trout Lake. Temperatures in pools and aquaria ranged from $16^{\circ}$ to $23^{\circ} \mathrm{C}$.

\section{Experimental animals}

Largemouth bass, Micropterus salmoides (250-275 $\mathrm{mm}$ total length [TL]), were collected from Carrol Lake, Oneida County, Wisconsin with electrofishing gear. Largemouth bass, housed in outdoor pools, were fed haphazardly chosen crayfish (all three species), minnows, and nightcrawlers.

Crayfish were hand collected by snorkeling in lake littoral zones. $O$. rusticus and $O$. propinquus were collected from Trout Lake, whereas $O$. virilis was collected from White Sand Lake, Vilas County, Wisconsin. Upon capture, crayfish carapace length (CL) was measured with vernier calipers to the nearest $0.5 \mathrm{~mm}$. Carapace length was defined as the distance between the rostral tip and posteromedian edge of the carapace. Unless otherwise stated, all CL size classes used in experiments were $\pm 1 \mathrm{~mm}$. Similar-sized crayfish were housed in aerated 10-L aquaria before experiments and fed fish flakes, trout chow, macrophytes (mostly Elodea spp. and (Cratophyllum spp.), and leaf detritus daily. Because most crayfish are nonovigerous or Form II (nonreproductive) during summer, only these life stages were used during experiments.

\section{Selective predation}

General methods. - In outside pools and laboratory aquaria, we quantified relative susceptibilities of equaland unequal-sized crayfish to largemouth bass predators starved for $24 \mathrm{~h}$. Less than $5 \%$ of the crayfish, marked with a uropod clip to monitor differential responses, were used in more than one trial. Experiments ran for 4-8 d and were replicated 3-10 times, each with a different largemouth bass. During these experiments, crayfish fed on decaying leaves and other detrital matter in the pools. To retrieve crayfish during experiments, we used a hand net and identified crayfish to species and sex. Consumed crayfish were not replaced. Upon crayfish return to pools, largemouth bass were restrained with a net until crayfish settled to the bottom.

We compared numbers of crayfish remaining at the 
end of each selective predation experiment using replicated ( $;$ tests (Sokal and Rohlf 1981), expecting equal consumption of each species. All cells were $X+1$ transformed such that pooled totals were $\geq 5$ (Sokal and Rohlf 1981). As a conservative test for selection, these analyses did not account for continued selection in the face of declining numbers of the preferred species.

Equal-sized cravfish. - At equal sizes, O. rusticus, $O$. propinquus, and $O$. virilis share similar morphological characteristics (Capelli and Capelli 1980). However, $O$. rusticus and $O$. propinquus males have larger chelae than $O$. virilis males or females (Garvey and Stein 1993). To determine if these three species were differentially susceptible to fish predation, we exposed equal-sized individuals to largemouth bass predation on sand, cobble, and macrophyte substrates. We then evaluated whether chela size differences contribute to differential vulnerability among the three congeners.

In most experiments, 10 O. rusticus, 100 . propinquus, and $10 \%$. virilis ( $1: 1$ sex ratio) were introduced at 0900 into outside pools ( $1.8 \mathrm{~m}$ diameter, $1 \mathrm{~m}$ depth). In experiments using $25 \mathrm{~mm}$ CL crayfish only, 5 male O. rusticus, $O$. propinquus, and $O$. virilis were used. Total crayfish densities were 12 individuals $/ \mathrm{m}^{2}$, well within natural densities (Capelli 1975, Lorman 1980). On sand, we tested differential selectivity at 15, 20, and $25 \mathrm{~mm} \mathrm{CL}$. For 15 and $20 \mathrm{~mm} \mathrm{CL}$, crayfish were checked at 1700 and 0900 for $4 \mathrm{~d}$. Because $25 \mathrm{~mm}$ crayfish were consumed slowly, $25 \mathrm{~mm}$ experiments ran for $8 \mathrm{~d}$ and were checked daily.

Crayfish are abundant on macrophyte and cobble substrates (Stein 1977, Saiki and Tash 1979, Kershner 1992). Therefore, we tested the relative susceptibilities of crayfish on both of these habitats. We quantified differential susceptibilities of $20 \mathrm{~mm}$ CL crayfish on macrophyte-covered substrates consisting of 150 shoots of Ceratophyllum spp. plus 50 shoots of Potamogeton spp. (total shoot density, 78.5 shoots $/ \mathrm{m}^{2}$, similar to densities in Trout Lake). Collected from Carrol Lake, shoots were weighted with rocks, which were then buried in sand. Similar experiments tested susceptibility on cobble (80-100 $\mathrm{mm}$ diameter) placed on sand at either high (200 pieces/pool) or low (50 pieces/pool) densities. Cobble densities in the field generally vary between these two extreme densities. All macrophyte and cobble experiments lasted $4 \mathrm{~d}$. When experiments were checked on day 2, all cobble and macrophyte shoots were removed, then replaced. We also determined whether chela size differences influenced differential vulnerability to predation by removing chelae of $15 \mathrm{~mm}$ CL crayfish and exposing them to largemouth bass predation on sand for $4 \mathrm{~d}$. Chela removal itself did not cause mortality in crayfish. In these experiments, crayfish were checked at 0900 and 1700 each day.

To explore the congruence in selectivity between outside pools and laboratory aquaria, we placed two
$O$. rusticus, two $O$. propinquus, two $O$. virilis ( 12 cray$\mathrm{fish} / \mathrm{m}^{2}$ density, $1: 1$ sex ratio, $20 \mathrm{~mm} \mathrm{CL}$ ) and a largemouth bass in a $200-\mathrm{L}$ aquarium with a sand bottom. After $4 \mathrm{~h}$, we recorded the number and species of crayfish consumed. Five replicates were performed.

Unequal-sized cravfish. - Although O. rusticus, $O$. propinquus, and $O$. virilis are morphologically similar, body sizes in the field are ordered $O$. virilis $>O$. rusticus $>$ O. propinquus throughout life (Corey 1988, Olsen et al. 1991). Because fish predators prefer small crayfish (Stein 1977), this size differential may influence susceptibility. By reducing $O$. propinquus size relative to $O$. rusticus size, we could evaluate if $O$. propinquus became more susceptible. In turn, by manipulating size differentials between $O$. virilis and the two invaders, $O$. propinquus and $O$. rusticus, we could determine if increasing $O$. virilis body size reduces $O$. virilis susceptibility to predation.

Our approach with unequal-sized crayfish in outside pool experiments was similar to that for equal-sized ones. Experiments were conducted on sand, begun at 0900 and checked at 0900 and 1700 each day for $4 \mathrm{~d}$. All CL size classes were $\pm 0.5 \mathrm{~mm}$. In our first experimental set, we exposed 10 each of $18 \mathrm{~mm} \mathrm{O.propin-}$ quus and $20 \mathrm{~mm}$ O. rusticus (1:1 sex ratio). We increased CL of $O$. rusticus by $1-\mathrm{mm}$ increments until O. propinquus became more susceptible to predation (at equal sizes, $O$. propinquus and $O$. rusticus were chosen equally in our experiments, see Results). Our second suite of experiments exposed 10 each of $18 \mathrm{~mm}$ CL O. rusticus, $18 \mathrm{~mm}$ CL O. propinquus, and $21 \mathrm{~mm}$ CL $O$. virilis ( $1: 1$ sex ratio) to largemouth bass predation. We increased $C L$ of $O$. virilis by $1-\mathrm{mm}$ increments until all three crayfish species were selected equally (at equal sizes, $O$. virilis was selected over $O$. rusticus and $O$. propinquus in our experiments, see $R \mathcal{C}$ sults).

\section{Cravfish interactions and behavior}

Prey interactions and behavior often determine susceptibility (Sih 1987). Thus, we examined how prey interactions and behavior influenced vulnerability in selection experiments by quantifying, for each species, (1) how predators influenced differential refuge use in outside pools, (2) individual responses to presence of congeners and predators, (3) effects of congeners on susceptibility to predation, and (4) individual aggression.

Shelter competition experiments. - To understand how refuge availability and predatory risk affect crayfish shelter use, we quantified differences in shelter use among these three crayfishes at two shelter densities in outside pools. Ten crayfish, $20 \mathrm{~mm} \mathrm{CL}$, of each species with a 1:1 sex ratio were introduced at 0900 to pools containing either 10 or 35 shelters. Shelters were lengthwise halves of polyvinyl chloride (PVC) plastic pipe cut into $5 \times 10 \mathrm{~cm}$ segments and embedded in sand-covered bottoms. Experiments lasted 2 d. For 2 
$\mathrm{d}$ before the experiment, crayfish were allowed to acclimate to pools with no predators. At 1700 on day 2 of the acclimation period, a satiated largemouth bass was introduced in five replicate sets of experimental treatments for both 10 shelters and 35 shelters. Thereafter, any crayfish consumed was replaced with a new crayfish marked with a clipped uropod. Controls without largemouth bass were replicated 4 times each. When experiments were checked daily at 1000 , shelters were retrieved and species/sex of the inhabitant was recorded. After all shelters were removed, remaining crayfish were captured. After largemouth bass addition, we compared proportion shelter use (pooled for the two experimental days) among species for the two shelter densities using a two-factor MANOVA with shelter density and fish predator presence as the two factors and shelter use for each species as dependent variables. Shelter use of individual species was analyzed using univariate ANOVAs. We also compared species survival in shelter experiments, again pooling data for the $2 \mathrm{~d}$, using a $G$ test, in which we expected equal consumption of all the three species.

Individual crayfish behavior. - Crayfish modify their behavior under predatory risk (Stein and Magnuson 1976). To understand underlying reasons for differential vulnerability, we quantified how other crayfish and largemouth bass influence crayfish behavior. Due to logistical constraints, only male crayfish behaviors were recorded, although females occurred in some treatments. No crayfish $(20 \mathrm{~mm} \mathrm{CL})$ were reused. Largemouth bass were starved $24 \mathrm{~h}$; if a crayfish was consumed during the experiment, we ended the trial. Four treatments, replicated at least 5 times, were as follows: (1) individual: one crayfish, no largemouth bass, plus no other crayfish; (2) individual plus congener: one crayfish, no largemouth bass, plus one female conspecific, plus one male and one female of each of the other species ( $N=6$ crayfish); (3) individual plus largemouth bass: one crayfish, one largemouth bass, plus no other crayfish; (4) individual plus largemouth bass and congeners: one crayfish, no largemouth bass, plus one female conspecific, plus one male and one female of each of the other species ( $N=6$ crayfish).

Crayfish were individually marked with typing correction fluid for easy identification, then introduced to the tanks for each 30-min trial. During each trial, male behavior was recorded every $10 \mathrm{~s}$ using a behavioral recorder (Datamyte 1000, Electro General Corporation) and a voice-activated tape recorder. Behaviors recorded were (1) chelae displays-crayfish posturing with chelae extended and spread, (2) activity levelcrayfish moving or stationary, and (3) swimmingcrayfish swimming in water column. For swimming observations, which were infrequent and easy to record, we quantified both male and female behaviors. Largemouth bass orientation to crayfish also was quantified. Proportion behaviors (number of each behavior recorded/frequency of all behaviors) during each 30 - min observation was arcsine- $\sqrt{x}$ transformed and analyzed with a two-way ANOVA for each species to test for effects of other crayfishes and fish predators (Wilkinson 1990). We also compared behavioral differences among species using individual one-way ANOVAs with post-hoc Tukey's multiple-comparisons tests. Largemouth bass orientation was analyzed with a replicated $G$ test (Sokal and Rohlf 1981).

Congeners and susceptibility to predation. - To assess whether interactions among crayfishes in pools influenced their susceptibility, we prevented crayfish from interacting by tethering them in outside pools with sand (as per Kershner 1992, Mather and Stein 1993, DiDonato and Lodge, in press). We used three male and three female $20 \mathrm{~mm}$ CL crayfish of each species. To tether crayfish, we tied $12 \mathrm{~cm}$ of monofilament line to swivels and then glued swivels to the cephalothorax using cyanoacrylate. Tethers were attached to clay tiles $(15.2 \times 15.2 \mathrm{~cm})$ buried in sand. Crayfish were arranged by grouping species, alternating males and females, along the pool perimeter. Species were grouped to minimize the chance of interspecific interactions caused by visual contact with nearby, tethered crayfish. Tethers allowed at least $10 \mathrm{~cm}$ between individuals. A largemouth bass predator, starved $24 \mathrm{~h}$, was introduced at 0900 and experiments were checked at 1700 and 0900 daily for $4 \mathrm{~d}$. Consumed crayfish were replaced. Crayfish consumed over the $4 \mathrm{~d}$ were compared among species using a replicated $G$ test (Sokal and Rohlf 1981).

Crayfish aggressive interactions. - Aggressive encounters between crayfish can influence reproduction (Capelli and Munjal 1982, Berrill and Arsenault 1984), acquisition of shelters (Capelli and Munjal 1982), competition for food (Hill and Lodge 1993), and susceptibility to predation (Stein 1977, Mather and Stein 1993. To evaluate the importance of aggression among the three congeners, we quantified aggression among equal sizes and unequal sizes of $O$. rusticus, $O$. propinquus, and $O$. virilis. Aggression was defined as "tension contacts" (Bovbjerg 1953) where one crayfish (the winner) caused another crayfish (the loser) to change direction during a confrontation. Experiments were done in 200-L aquaria on sand, lasted $1 \mathrm{~h}$, and were replicated at least 5 times. One male and one female of each species were used for each trial. Because males tend to be more aggressive than females (Berrill and Arsenault 1984) and intermale conflicts within species might influence susceptibility, we also quantified intermale behavior between two males of each species in another set of five trials. We did not observe interfemale conflicts. During each trial, total number of fights and outcomes of each fight were recorded. For equal sizes, $20 \mathrm{~mm}$ CL crayfish were used. For unequal-sized crayfish, initially $18-\mathrm{mm} \mathrm{CL} O$. rusticus and $18-\mathrm{mm} \mathrm{CL} O$. propinquus were placed with $21-\mathrm{mm} \mathrm{CL} O$. virilis, the same size differential as in size-selection experiments. We then increased $O$. virilis CL by $1 \mathrm{~mm}$ until $O$. virilis 

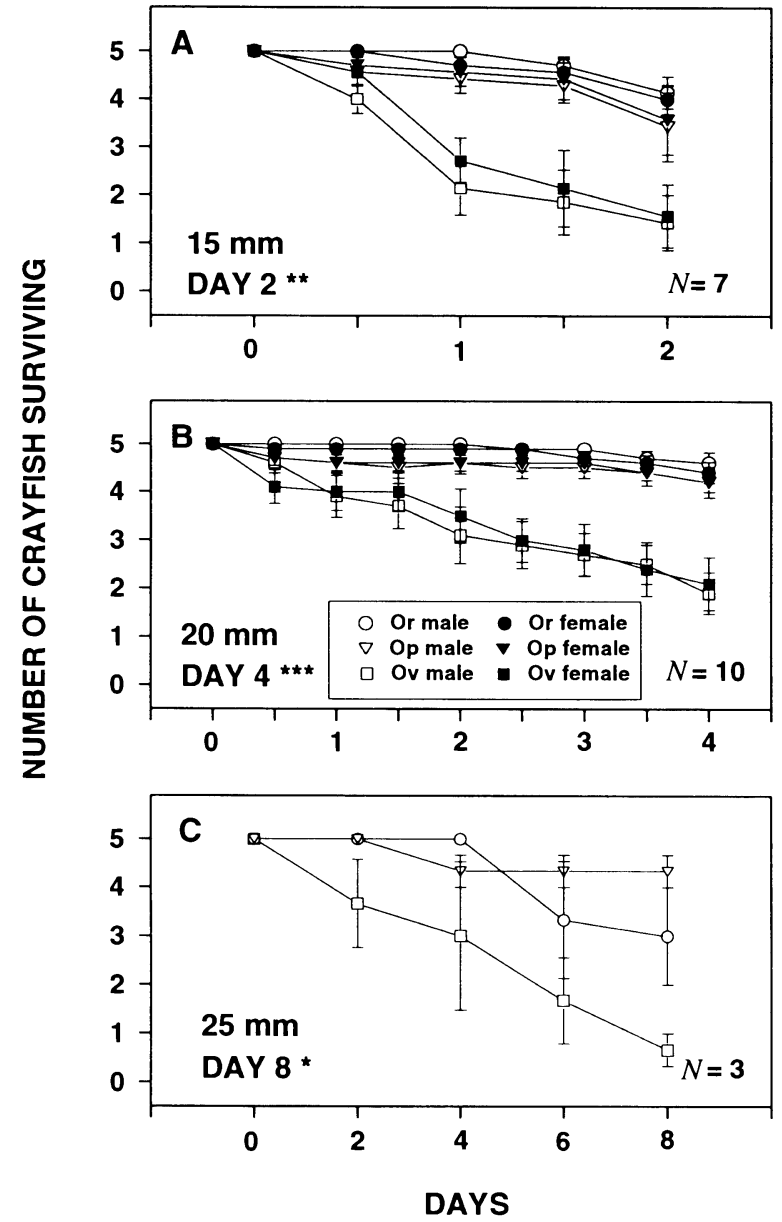

F1G. 1. Number of equal-sized Orconectes rusticus (Or), $O$. propinquus $(\mathrm{Op})$, and $O$. virilis $(\mathrm{Ov})$ surviving largemouth bass predation for three crayfish carapace length classes $(C L$ $\pm 1 \mathrm{~mm}$ ) on sand in $1.8 \mathrm{~m}$ diameter outside pools through time (note differences in $x$ axis scale among panels). Means are given \pm 1 SE. Statistics are results of replicated $G$ tests comparing number of each species remaining on final day of each experiment (see lower left of each panel). NS $P>.05$; ${ }^{*} P \leq .05 ;{ }^{* *} P<.01 ; * * * P<.001$.

won more fights than the other two species (at equal sizes, $O$. virilis was less aggressive, Capelli and Munjal 1982, our study). Number of fights won for each sex and species was analyzed using replicated $G$ tests (Sokal and Rohlf 1981).

With vernier calipers, we measured chela length (palm length) of each crayfish to determine whether chela size influenced outcome of fights. For 20-mm CL crayfish, chela length differences between the winner and loser of each tension contact were regressed against proportion of fights won (number of fights won/total number of fights during that 1 -h bout). These relationships were analyzed using linear regression (Wilkinson 1990). We also determined whether increasing body or chela size differences influenced $O$. virilis aggression using multiple-regression analyses (Wilkinson 1990) where pro- portion fights won during each bout was the dependent variable, and body and chela size differences between $O$. virilis and the invaders were the independent variables.

\section{RESULTS}

\section{Selective predation}

Within species, male and female susceptibility did not differ ( $G$ test, $P>.05$ ); thus, we pooled male and female data. Because replicates were homogeneous ( $G$ test for heterogeneity, $P>.10$ ), they were pooled. The small number of reused crayfish did not differ in susceptibility from naive crayfish $(G$ test, $P>.10)$. Apparently, crayfish did not learn to avoid fish predators with increased experience.

Equal-sized crayfish. - Largemouth bass consistently chose $O$. virilis over equal-sized $O$. rusticus and $O$. propinquus for 15-, 20-, and 25-mm CL size classes on

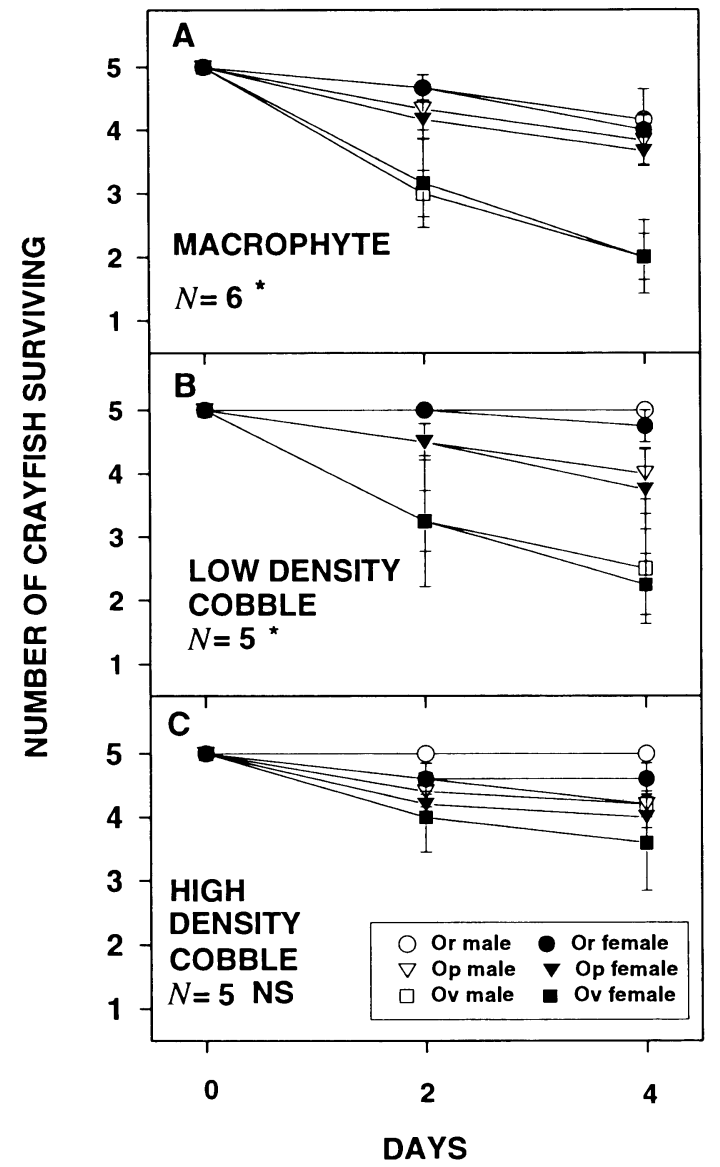

Fig. 2. Number of equal-sized $O$. rusticus (Or), O. propinquus $(\mathrm{Op})$, and $O$. virilis $(\mathrm{Ov})$ surviving after $4-\mathrm{d}$ exposure to fish predation with high density of cobble ( 200 pieces/pool) low density of cobble ( 50 pieces/pool), and macrophytes ( 78.5 shoots $\left./ \mathrm{m}^{2}\right)$ available as bottom structure in $1.8 \mathrm{~m}$ diameter outside pools through time. All crayfish were $20-\mathrm{mm}$ CL (carapace length). Means are shown \pm 1 SE. Statistics are results of replicated $G$ tests comparing number of each species remaining on day 4 . NS $P>.05 ;^{*} P \leq .05$. 


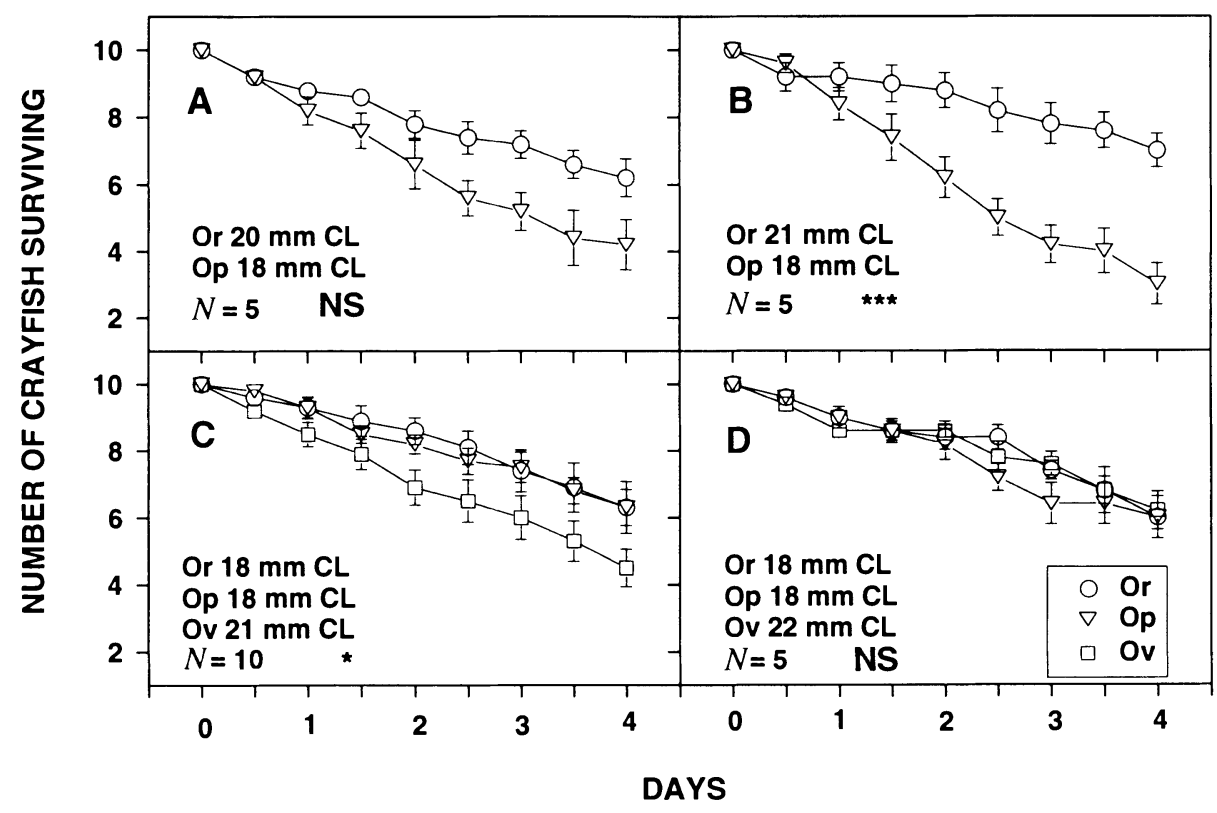

FIG. 3. Number of unequal-sized crayfish surviving after $4 \mathrm{~d}$ of largemouth bass predation on sand in $1.8 \mathrm{~m}$ diameter outside pools. Top panels $(\mathrm{A}, \mathrm{B})$ reveal effects of reducing $O$. propinquus $(\mathrm{Op})$ size on susceptibility; bottom panels $(\mathrm{C}, \mathrm{D})$ reveal effects of increasing $O$. virilis $(\mathrm{Ov}) \mathrm{CL}$ on differential susceptibility of $O$. rusticus $(\mathrm{Or})$ and $O$. propinquus. Means are shown \pm 1 SE. Replicated $G$ tests were performed on number of crayfish remaining on day 4 . NS $P>.05 ; *^{*} P \leq .05 ;{ }^{* * *} P<$ .001 .

sand ( $G$ test, $P<.05$, Fig. 1). Number of $O$. rusticus and $O$. propinquus remaining by the end of experiments did not differ ( $G$ test, $P>.10$, Fig. 1). Patterns in $200-\mathrm{L}$ aquaria with sand substrates matched those in outside pools. During five replicate trials, more $O$. virilis (1.4 \pm 0.24 individuals, mean $\pm 1 \mathrm{SE}$ ) were consumed than either $O$. rusticus or $O$. propinquus ( 0 consumed) after $4 \mathrm{~h}$ with a starved largemouth bass.

When substrates were macrophytes or low density cobble, $O$. virilis also was selected by largemouth bass ( $G$ test, $P<.05$, Fig. 2A, B). Apparently, these substrates did not provide adequate cover for crayfishes, especially $O$. virilis. At high cobble density, $O$. virilis was no longer selected ( $G$ test, $P>.10$, Fig. 2C) simply because crayfish were eaten quite infrequently. Most likely, largemouth bass became less selective as prey capture rates declined (MacArthur and Pianka 1966).

Recall that $O$. rusticus and $O$. propinquus males have longer and wider chelae than $O$. virilis (Garvey and Stein 1993). Yet, after we removed chelae from all three species, 15-mm CL $O$. virilis was still highly selected over same-sized $O$. rusticus and $O$. propinquus ( $G$ test, $N=3, P<.05)$. Thus, mechanisms other than chela size differences contribute to differential vulnerability.

Unequal-sized cravfish. - To further understand how predation influences the ability of both $O$. rusticus and $O$. propinquus to replace $O$. virilis, natural differences in crayfish body sizes ordered $O$. virilis $>O$. rusticus $>$ O. propinquus within each age class (Corey 1988, Olsen et al. 1991) also must be considered. Within a species, fish predators choose small crayfish over large ones (Stein 1977). O. propinquus that were $2 \mathrm{~mm}$ smaller than $O$. rusticus were chosen equally ( $G$ test, $P>$ .10 , Fig. 3A), but $O$. propinquus that were $3 \mathrm{~mm}$ smaller than $O$. rusticus were consumed more often by day 4 ( $G$ test, $P<.05$, Fig. 3B).

Although size-selective predation contributes to the differential susceptibility of $O$. propinquus, for $O$. virilis, which grows larger than either invader, factors other than body size differences were involved. For example, $3 \mathrm{~mm}$ larger $O$. virilis still was selected over $O$. rusticus and $O$. propinquus $(G$ test, $P<.05$, Fig. $3 \mathrm{C})$. When $O$. virilis were $4 \mathrm{~mm}$ larger, all three crayfishes survived fish predation equally ( $G$ test, $P>.05$, Fig. 3D). We caution, however, that in these experiments sample sizes differed between the 3-mm $(N=$ 10) and 4-mm $(N=5)$ difference experiments (Fig. 3C, D). Potentially, we detected susceptibility patterns in the 3-mm differential experiment because sample sizes were greater. Perhaps if we increased sample sizes in 4-mm difference experiments, we again would have found vulnerability differences. Therefore, we can only cautiously conclude that increasing size decreases susceptibility of $O$. virilis.

\section{Cravfish interactions and behavior}

Shelter competition experiments. - We compared among-species differences in shelter use after largemouth bass addition (pooled for $2 \mathrm{~d}$ ). Both increasing shelter availability and introducing largemouth bass caused all three species to increase shelter use (twoway MANOVA, Fish and Shelter effects, $P<.001$, 


\section{0 shelters available $\quad 35$ shelters available}

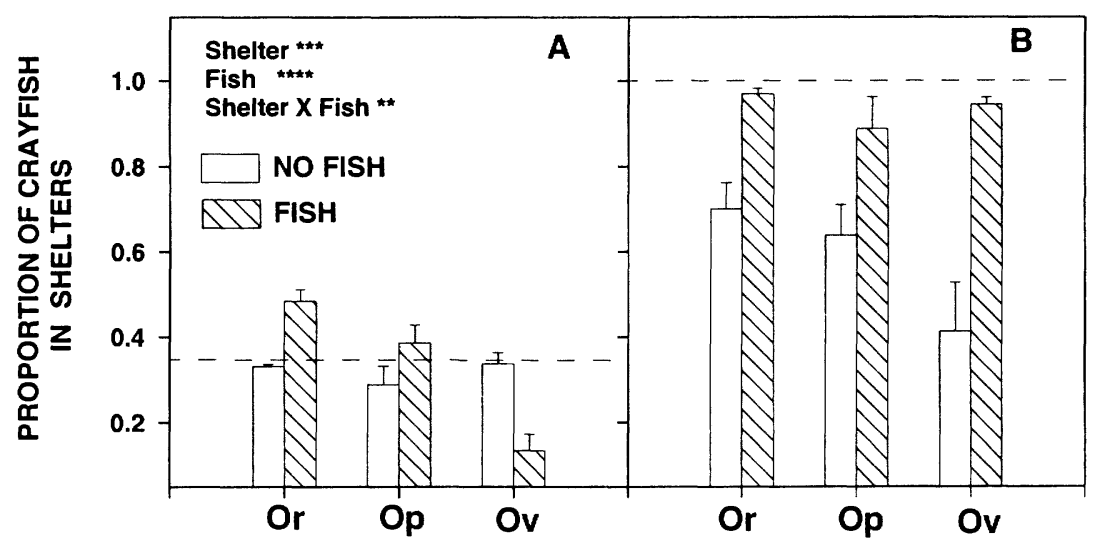

FIG. 4. Proportion of $10 \mathrm{O}$. rusticus (Or), $10 \mathrm{O}$. propinquus $(\mathrm{Op})$, and $10 \mathrm{O}$. virilis $(\mathrm{Ov})$ in shelters for $2 \mathrm{~d}$ (pooled percentages, mean and $1 \mathrm{SE}$ ) after largemouth bass were added to $1.8 \mathrm{~m}$ diameter outside pools. Shelter was either limited (panel A: 10 shelters) or unlimited (panel B: 35 shelters). Dashed lines are expected shelter use if all three species used shelters equally. Statistics result from two-way MANOVA examining species (Shelter) and largemouth bass (Fish) effects for the two shelter treatments. Only significant $(P \leq .05)$ effects within a treatment are plotted. See Table 1 for MANOVA and univariate ANOVA results. ${ }^{* *} P<.01 ; * * * P<.001 ; * * * * P<.0001$

Fig. 4A, B, Table 1). A significant Shelter $\times$ Fish interaction from both the conservative MANOVA analysis which includes all dependent variables $(P=.004$, Table 1) and for the corresponding ANOVA decomposition for $O$. virilis (ANOVA, $P=.0002$, Table 1) indicated that $O$. virilis was unable to acquire limited shelters when fish predators were present, potentially due to exclusion by other crayfish (Fig. 4A). Apparently, with largemouth bass plus unlimited shelters, all three species increased shelter use to avoid predation. However, when shelters were limited, $O$. virilis was excluded from shelters by the two invading species.

Susceptibility patterns in shelter experiments were similar to those in other outside pool selectivity experiments. Slightly more $O$. virilis $(2.2 \pm 0.56$ individuals [mean $\pm 1 \mathrm{SE}$ ]) than $O$. propinquus $(1.2 \pm 0.21)$ and $O$. rusticus $(0.6 \pm 0.17)$ were consumed during all

TABLE 1. Results of two-way MANOVA and univariate ANOVAs for proportion of shelter use by 10 Orconectes rusticus $(\mathrm{Or}), 10$ O. propinquus $(\mathrm{Op})$, and 10 O. virilis $(\mathrm{Ov})$ in outside pools with 10 shelters (limited) or 35 shelters (unlimited) available for 30 crayfish. Results are pooled across 2 d. See Fig. 4 for related data.

\begin{tabular}{lcccc}
\hline \hline \multirow{4}{*}{ Effect } & $\begin{array}{c}\text { Variable } \\
\text { (propor- }\end{array}$ & & & \\
tion in & ANOVA & Wilks' & MANOVA \\
shelter) & $P$ & $\lambda$ & $P$ \\
\hline Shelter & Or & .0001 & 0.052 & .001 \\
& Op & .0001 & & \\
Fish & Ov & .0001 & & \\
& Or & .0001 & 0.132 & .0001 \\
\multirow{5}{*}{ Shelter $\times$ Fish } & Op & .0041 & & \\
& Ov & .0060 & & \\
& Or & .9839 & 0.337 & .004 \\
& Op & .4622 & & \\
& Ov & .0002 & & \\
\hline
\end{tabular}

shelter experiments ( $G$ test, $\mathrm{df}=2, G=6.98, P<.05$ ). More crayfish tended to be consumed with unlimited shelters $(2.2 \pm 0.37)$ than with limited shelters ( $G$ test, $\mathrm{df}=1, G=3.95, P<.05$ ). Due to low consumption rates, we were unable to analyze differential species susceptibilities for each individual shelter density.

Individual crayfish behavior. - In treatments without largemouth bass, using one-way ANOVA comparisons across species, we found that $O$. virilis was less active than $O$. propinquus (Tukey's multiple-comparisons, $P$ $=.001$, Fig. 5A) whereas $O$. rusticus activity did not differ from either $O$. propinquus or $O$. virilis (Tukey's multiple-comparisons, $P>.05$, Fig. 5A). Largemouth bass reduced activity levels of all three species (twoway ANOVA, Fish effect, $P<.0001$, Fig. 5A, Table 2 ). However, in the individual plus largemouth bass treatment, $O$. virilis decreased activity more than the two invaders (Tukey's multiple-comparisons, $P=.002$, Fig. 5A). Although addition of congeners to tanks containing individual crayfish did not influence crayfish activity, congeners plus largemouth bass increased activity of $O$. virilis relative to its activity with largemouth bass only (two-way ANOVA, Fish $\times$ Congener effect, $P<.05$, Fig. 5A, Table 2). Interestingly, in the individual plus congeners and largemouth bass treatment, $O$. virilis activity no longer differed from that of the two invaders (one-way ANOVA, $P>.05$, Fig. 5A). Indeed, $O$. virilis, the most vulnerable species, did reduce activity more in the face of predation, possibly to avoid detection by the predator. However, interactions with other crayfish increased $O$. virilis activity levels, thereby confounding this predator avoidance behavior.

With no congeners present, largemouth bass orientations to crayfish increased chelae displays of all three species (two-way ANOVA, $P<.05$, Fig. 5B, Table 2). 
Without largemouth bass present, introduction of congeners to tanks with individual crayfish did not influence crayfish chelae displays (Fig. 5B, Table 2). With a largemouth bass present, however, increasing the number of crayfish in a treatment could reduce the frequency of individual chelae displays simply because fish were orienting on six individuals rather than one. Indeed. other crayfishes reduced $O$. propinquus chelae displays (two-way ANOVA, $P=.021$, Fig. 5B. Table 2) relative to treatments without other crayfishes. Using one-way ANOVAs to compare chelae displays among crayfishes for each treatment, we found that $O$. virilis displayed chelae less frequently than $O$. propinquus (Tukey's multiple-comparisons, $P=.010$, Fig. 5B) and, possibly, $O$. rusticus (Tukey's multiple-comparisons, $P=.094$. Fig. 5B). O. rusticus and $O$. propinquus displayed chelae similarly (Tukey's multiple-comparisons, $P>.05$. Fig. 5B). In experiments, $O$. rusticus and $O$. propinquus were quite aggressive toward largemouth bass, often walking toward fish predators with chelae raised. Conversely, $O$. virilis, rather than posturing with chelae spread in response to a predatory threat. simply reduced its activity.

O. virilis also swam more frequently $(N=29$ swim flights; duration $7.5 \pm 0.8 \mathrm{~s}$ [mean $\pm 1 \mathrm{sE}$ ], range 2$18 \mathrm{~s}$ ) and far longer than the invaders, which rarely swam. These swim flights ranged $20-30 \mathrm{~cm}$ above the bottom. O. propinquus and O. rusticus swam in $<0.5 \%$ of trials, with no swim flight exceeding $3 \mathrm{~s}$. Because the number of $O$. virilis male and female swim flights per treatment did not differ (two-way ANOVA, $P>$ $.5)$, we pooled sexes in analyses. Both congeners and largemouth bass increased the frequency of $O$. virilis
Activity levels Chelae displays

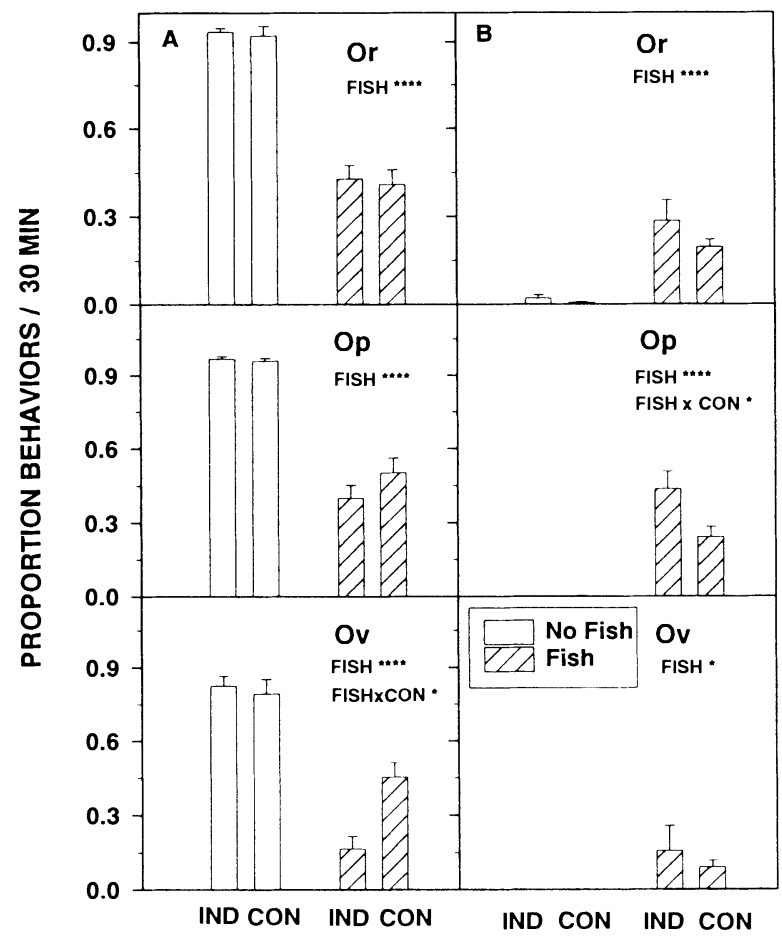

FIG. 5. Proportion of observations of crayfish activity (A column) and chelae displays (B column) of the three species during $30-\mathrm{min}$ observations in $200-\mathrm{L}$ aquaria as affected by largemouth bass (Fish), absence of other crayfishes (Ind), and one conspecific plus four crayfishes of the other species (Con). Data are means and 1 SE. Only significant $(P<.05)$ treatment effects of two-way ANOVA are presented. See Table 2 for two-way ANOVA results. ${ }^{*} P \leq .05 ;{ }^{* * * *} P<.0001$.

TABLE 2. Two-way ANOVA results for proportion chelac displays, proportion activity levels, and number of swim flights influenced by largemouth bass (Fish) and congeners (Con) during 30-min observations. Orconectes rusticus (Or) and $O$. propinquus $(\mathrm{Op})$ never participated in swim flights in the presence of largemouth bass.

\begin{tabular}{|c|c|c|c|c|c|c|c|}
\hline Experiment & $\begin{array}{c}\text { Texi } \\
\text { location }\end{array}$ & Species & $\begin{array}{l}\text { Source of } \\
\text { variation }\end{array}$ & $\mathrm{df}$ & MS & $F$ & $P$ \\
\hline \multirow[t]{9}{*}{ Activity levels } & Fig. 5A & Or & Fish & 1 & 1.57 & 46.86 & .0001 \\
\hline & & & Con & 1 & 0.002 & 0.066 & NS \\
\hline & & & Fish $\times$ Con & 1 & 0.003 & 0.095 & NS \\
\hline & & Op & Fish & 1 & 2.27 & 75.07 & .0001 \\
\hline & & & Con & 1 & 0.00 & 0.012 & NS \\
\hline & & & Fish $\times$ Con & 1 & 0.033 & 1.08 & NS \\
\hline & & $\mathrm{Ov}$ & Fish & 1 & 2.03 & 41.11 & .0001 \\
\hline & & & Con & 1 & 0.014 & 0.29 & NS \\
\hline & & & Fish $\times$ Con & 1 & 0.25 & 5.08 & .033 \\
\hline \multirow[t]{9}{*}{ Chelae displays } & Fig. 5B & Or & Fish & 1 & 0.22 & 25.30 & .0001 \\
\hline & & & Con & 1 & 0.001 & 0.082 & NS \\
\hline & & & Fish $\times$ Con & 1 & 0.012 & 1.34 & NS \\
\hline & & Op & Fish & 1 & 0.63 & 44.98 & .0001 \\
\hline & & & Con & 1 & 0.00 & 0.00 & NS \\
\hline & & & Fish $\times$ Con & 1 & 0.084 & 6.05 & .021 \\
\hline & & $\mathrm{Ov}$ & Fish & 1 & 0.081 & 5.23 & .030 \\
\hline & & & Con & 1 & 0.00 & 0.00 & NS \\
\hline & & & Fish $\times$ Con & 1 & 0.010 & 0.65 & NS \\
\hline \multirow[t]{3}{*}{ Swim flights } & Fig. 6 & $\mathrm{Ov}$ & Fish & 1 & 9.39 & 4.36 & .042 \\
\hline & & & Con & 1 & 9.19 & 4.27 & .044 \\
\hline & & & Fish $\times$ Con & 1 & 3.72 & 1.73 & NS \\
\hline
\end{tabular}




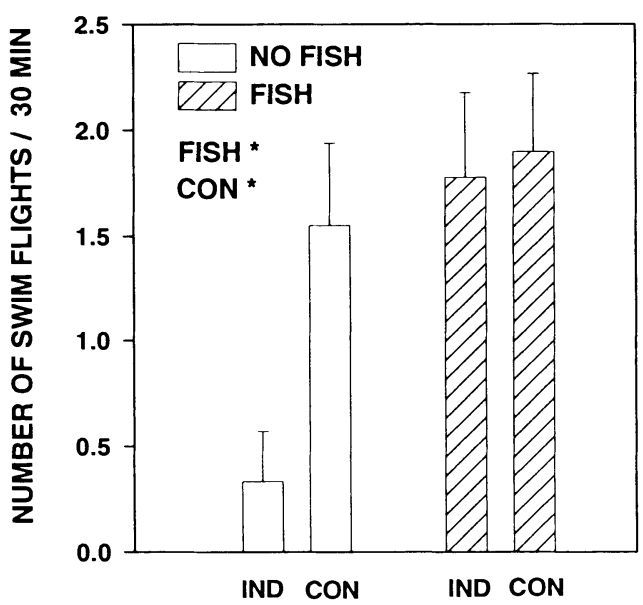

FIG. 6. Number of $O$. virilis swim flights $>2$-s duration as affected by largemouth bass (Fish), absence of other crayfishes (Ind), and one conspecific plus four invaders (Con). Data are means and I SE. Only significant $(P \leq .05)$ treatment effects of two-way ANOVA are presented. See Table 2 for ANOVA results. ${ }^{*} P \leq .05$.

swim flights (two-way ANOVA, $P<.05$, Fig. 6 , Table 2 ), but neither congeners nor largemouth bass influenced swim flight duration (two-way ANOVA, $P>.5$ ). Swimming crayfish, unable to use chelae for defense. are easily consumed (Stein 1977, Mather and Stein 1993). Indeed, on four occasions, $O$. virilis swim flights resulted in consumption by largemouth bass. Therefore, $O$. virilis clearly was at a disadvantage when par- ticipating in this behavior. When $O$. rusticus, $O$. propinquus, and $O$. virilis occurred together, largemouth bass oriented on all sexes and species equally ( $G$ test, $P>.5$ ). Therefore, $O$. virilis behaviors were not caused by preferential largemouth bass orientations. Both the presence of invaders and predators initiated potentially lethal swim flights for $O$. virilis.

Congeners and susceptibility to predation. - Interactions among crayfishes appear to be important in determining susceptibility to fish predation. However, when crayfish in outside pools were prevented from interacting via tethering, only $O$. virilis was consumed by largemouth bass during four trials (mean $\pm 1 \mathrm{SE}=$ $1.5 \pm 0.29$ individuals); neither tethered $O$. rusticus nor $O$. propinquus were eaten during these 4 -d treatments. Apparently, individual activities, such as infrequent chelae displays and swimming, were sufficient to increase the susceptibility of $O$. virilis to largemouth bass.

Cravfish aggressive interactions. - Although individual behavior alone appeared to place $O$. virilis at great predatory risk, agonistic interactions with other crayfishes influenced swim flights, refuge use, and activity. In experiments where we observed agonistic tension contacts, all 1-h duration replicates were homogeneous ( $G$ test, $P>.10$ ) and, therefore, were pooled for analysis. Similar to Capelli and Munjal (1982), we found that, in male-female experiments, $O$. virilis males and females lost most fights with equal-sized $O$. rusticus and $O$. propinquus males and females $(G$ test, $P<.05$,

TABLE 3. Number of tension contacts won and results of replicated $G$ tests (pooled results) between crayfish 1 (Cf1) and crayfish 2 (Cf2) during I-h observations in 200-L aquaria. Two each of the three Orconectes species were used for each replicate in both intra-and interspecific trials. Treatments were $O$. virilis $(\mathrm{Ov})$ same size as congeners, Ov 3-mm CL (carapace

\begin{tabular}{|c|c|c|c|c|c|c|c|}
\hline \multirow[b]{4}{*}{ Interaction } & \multirow{2}{*}{\multicolumn{4}{|c|}{ Crayfish equal-sized }} & \multicolumn{3}{|c|}{ Ov $3 \mathrm{~mm}$ larger } \\
\hline & & & & & \multirow[b]{3}{*}{$P$} & \multirow{3}{*}{$\frac{\text { Contestants }}{\text { Cfl vs. Cf2 }}$} & \multirow{3}{*}{$\begin{array}{c}\begin{array}{c}\text { Numbe } \\
\text { of fight } \\
\text { won }\end{array} \\
\text { Cfl }\end{array}$} \\
\hline & \multirow{2}{*}{$\frac{\text { Contestants }}{\text { Cfl vs. Cf } 2}$} & \multicolumn{2}{|c|}{$\begin{array}{l}\text { Number of } \\
\text { fights won }\end{array}$} & \multirow[b]{2}{*}{$G$} & & & \\
\hline & & Cfl & $\mathrm{Cf} 2$ & & & & \\
\hline \multirow{3}{*}{ Intraspecific } & Orô vs. Or̊ & 64 & 27 & 12.12 & $* * *$ & Orỡ vs. Or̊ & 14 \\
\hline & 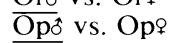 & 85 & 44 & 17.99 & $* * * *$ & Ops vs. Opq & 3 \\
\hline & $\overline{\mathrm{Ov} \delta}$ vs. Ovq & 26 & 30 & 0 & NS & Ovô vs. Ovq & 13 \\
\hline \multirow[t]{15}{*}{ Interspecific } & Orồ vs. Op & 48 & 59 & 0.76 & NS & Orồ vs. Oppồ & 16 \\
\hline & Orô vs. Ovô & 65 & 9 & 43.32 & $* * * *$ & $\overline{\mathrm{Orô}}$ vs. Ovồ & 14 \\
\hline & $\overline{O p \delta}$ vs. Ovô & 76 & 13 & 37.22 & $* * * *$ & 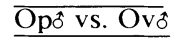 & 5 \\
\hline & Orồ vs. Opsờ & 38 & 95 & 25.24 & $* * * *$ & & \\
\hline & Orồ vs. Ovờt & 53 & 36 & 3.27 & NS & & \\
\hline & Opô vs. Ovơt & 93 & 27 & 59.0 & $* * * *$ & & \\
\hline & Orq vs. Opq & 53 & 35 & 2.91 & NS & Orq vs. Opq & 9 \\
\hline & Orq vs. Ovq & 55 & 15 & 17.99 & $* * * *$ & Orq vs. Ovq & 3 \\
\hline & $\overline{\mathrm{Op} q}$ vs. Ovq & 54 & 26 & 7.63 & $* *$ & Opq vs. $\overline{\mathrm{Ov} q}$ & 16 \\
\hline & $\overline{\mathrm{Or} \delta}$ vs. Opq & 33 & 48 & 0.14 & NS & $\overline{\text { Orô vs. Op } q}$ & 9 \\
\hline & $\overline{\mathrm{Or}^{\wedge} \mathrm{vs} . \mathrm{O} \mathrm{Ov} q}$ & 69 & 14 & 29.67 & $* * * *$ & $\overline{\text { Orô vs. Ov } q}$ & 11 \\
\hline & $\overline{\mathrm{Op} \delta}$ vs. Oro & 70 & 68 & 0.02 & NS & Ops vs. Orq & 3 \\
\hline & $\overline{\mathrm{Op} \delta \text { ss. } \mathrm{Ov} q}$ & 90 & 15 & 46.47 & $* * * *$ & Opố vs. Ovq & 6 \\
\hline & $\overline{\mathrm{Ovô}}$ vs. Oro & 14 & 67 & 28.02 & $* * * *$ & Ovo vs. Or $q$ & 19 \\
\hline & $\mathrm{Ov}{ }^{\wedge}$ vs. $\overline{\mathrm{Op}}$ & 21 & 56 & 12.38 & $* * *$ & $\overline{\mathrm{Ov} \delta}$ vs. Op? & 3 \\
\hline
\end{tabular}

${ }^{*} P<.05,{ }^{* *} P<.01,{ }^{* * *} P<.001,{ }^{* * * *} P<.0001$.

$\dagger$ Male-only fights; otherwise sex ratio was $1: 1$. 
Table 3). In male-only experiments, $O$. rusticus won only a few more fights with $O$. virilis ( $G$ test, $.10>P$ $>.05$. Table 3$)$ and even fewer fights with $O$. propinquus ( $(r$ test, $P<.05$, Table 3$)$. As in male-female experiments, $O$. propinquus males won most fights with $O$. virilis males ( $G$ test, $P<.05$, Table 3 ). We cannot explain why $O$. rusticus males were less successful in male-only experiments. Perhaps the presence of conspecific males influenced fight outcomes. However, $O$. virilis was consistently less successful in aggressive encounters with $O$. rusticus or $O$. propinquus.

At equal sizes, $O$. virilis males and females fought each other less frequently than male and female invaders ( $G$ test, $\mathrm{df}=2, G=29.62, P<.05$, Table 3$)$. Also, in male-only observations, more interspecific $(N$ $=342)$, rather than intraspecific, fights $(N=71)$ occurred among males of the three species ( $G$ test, $P<$ $.05)$. In male-female experiments within species, $O$. rusticus and $O$. propinquus males won more agonistic bouts than females $(G$ test, $P<.05$, Table 3$)$, whereas $O$. virilis males and females were equally aggressive (Table 3). Thus, for O. virilis, interspecific fights most likely occurred more frequently than intraspecific ones in selective predation experiments.

With increasing body size, $O$. virilis won more fights with $O$. rusticus and $O$. propinquus. Interestingly, when $O$. virilis were $3 \mathrm{~mm}$ larger than $O$. rusticus and $O$. propinquus, males won an equal number of fights (Table 3 ). However, $O$. virilis males and females won more tension contacts than $O$. rusticus females ( $G$ test, $P<$ .05 . Table 3 ). When $O$. virilis were $4 \mathrm{~mm}$ larger, $O$. virilis dominated the invaders $(G$ test, $P<.05$, Table 3 ). For both CL size differences, large $O$. virilis apparently reduced the total number of agonistic bouts during each 1 -h trial (Table 3 ). Although $O$. virilis appears innately less aggressive, i.e., less able to win tension contacts than the invading species, a fairly large body size differential reverses the outcome of equal-sized interactions.

Chela length increases with body size (Garvey and Stein 1993). Large chelae positively influenced the number of interspecific fights won among all crayfishes except $O$. virilis females, in that, as chela size differences between the winner and loser increased, the likelihood of winning increased ( $F$ test, $P<.05$, Fig. 7). When exploring the relative contribution of increasing body and chela size differences to $O$. virilis dominance over $O$. rusticus and $O$. propinquus, both increasing body and chela size differences were important for $O$. virilis males (multiple regression, $N=85, R^{2}=0.58$; for body size, $T=5.58, P<.0001$; for chela size, $T$ $=1.95, P<.055$ ). However, for female $O$. virilis, only increasing body size differences influenced the number of fights won over O. rusticus and $O$. propinquus (multiple regression, $N=85, R^{2}=0.50$; for body size, $T=$ 6.08, $P<.0001)$.

\section{DISCUSSION}

We propose that two mechanisms contribute to the replacement of $O$. propinquus and $O$. virilis by $O$. rusticus. Large $O$. rusticus replaces its small congener $O$. propinquus, in part due to size-selective predation by

length) larger, and Ov 4-mm CL larger. Contestants not sharing a common underline won significantly $(P<.05)$ different numbers of fights.

\begin{tabular}{|c|c|c|c|c|c|c|c|}
\hline \multicolumn{3}{|c|}{ Ov $3 \mathrm{~mm}$ larger } & \multirow{2}{*}{\multicolumn{5}{|c|}{ Ov $4 \mathrm{~mm}$ larger }} \\
\hline \multirow{3}{*}{$\begin{array}{c}\begin{array}{c}\text { Number } \\
\text { of fights } \\
\text { won }\end{array} \\
\text { Cf } 2\end{array}$} & \multirow[b]{3}{*}{ G } & \multirow[b]{3}{*}{$P$} & & & & & \\
\hline & & & \multirow{2}{*}{$\frac{\text { Contestants }}{\text { Cfl vs. Cf }}$} & \multicolumn{2}{|c|}{$\begin{array}{l}\text { Number of } \\
\text { fights won }\end{array}$} & \multirow[b]{2}{*}{$G$} & \multirow[b]{2}{*}{$P$} \\
\hline & & & & $\mathrm{Cfl}$ & $\mathrm{C} 2$ & & \\
\hline 6 & 2.16 & NS & Orờ vs. Or̊ & $\cdots$ & $\cdots$ & $\cdots$ & $\cdots$ \\
\hline 9 & 1.83 & NS & Opŝ vs. Op? & 5 & 3 & 0.22 & NS \\
\hline 16 & 0.23 & NS & Ovo vs. Ovq & 18 & 18 & 0 & NS \\
\hline 5 & 3.99 & $*$ & Orồ vs. Op $\hat{\jmath}$ & 6 & 6 & 0 & NS \\
\hline 9 & 0.81 & NS & $\overline{\mathrm{Orô}}$ vs. $\mathrm{Ov}_{\hat{o}}$ & 0 & 16 & 11.64 & $* * *$ \\
\hline 12 & 1.84 & NS & Opồ vs. $\underline{\overline{\mathrm{Ov} \hat{\jmath}}}$ & 4 & 24 & 11.08 & $* * *$ \\
\hline 16 & 1.41 & NS & Orq vs. Op? & 10 & 5 & 1.01 & NS \\
\hline 15 & 5.31 & $*$ & $\overline{\text { Orq vs. } \mathrm{Ov} q}$ & 1 & 12 & 6.06 & $* *$ \\
\hline 6 & 3.18 & NS & $\mathrm{Op} q$ vs. $\overline{\mathrm{Ov} q}$ & 0 & 20 & 14.56 & $* * * *$ \\
\hline 10 & 0.03 & NS & Orô vs. Op? & 1 & 1 & 0 & NS \\
\hline 12 & 0.03 & NS & $\overline{\mathrm{Op}^{\hat{\alpha}} \mathrm{vs} . \mathrm{O} \mathrm{Ov} q}$ & 0 & 28 & 23.09 & $* * * *$ \\
\hline 8 & 1.20 & NS & Opồ vs. Oro & 3 & 7 & 1.01 & NS \\
\hline 9 & 0.36 & NS & Opô vs. Ov? & 2 & 20 & 10.74 & $* *$ \\
\hline 5 & 5.94 & $*$ & Ovơ vs. Oro & 15 & 0 & 9.64 & $* *$ \\
\hline 14 & 5.01 & $*$ & $\overline{\mathrm{Ovô}}$ vs. Opq & 26 & 0 & 20.89 & $* * * *$ \\
\hline
\end{tabular}




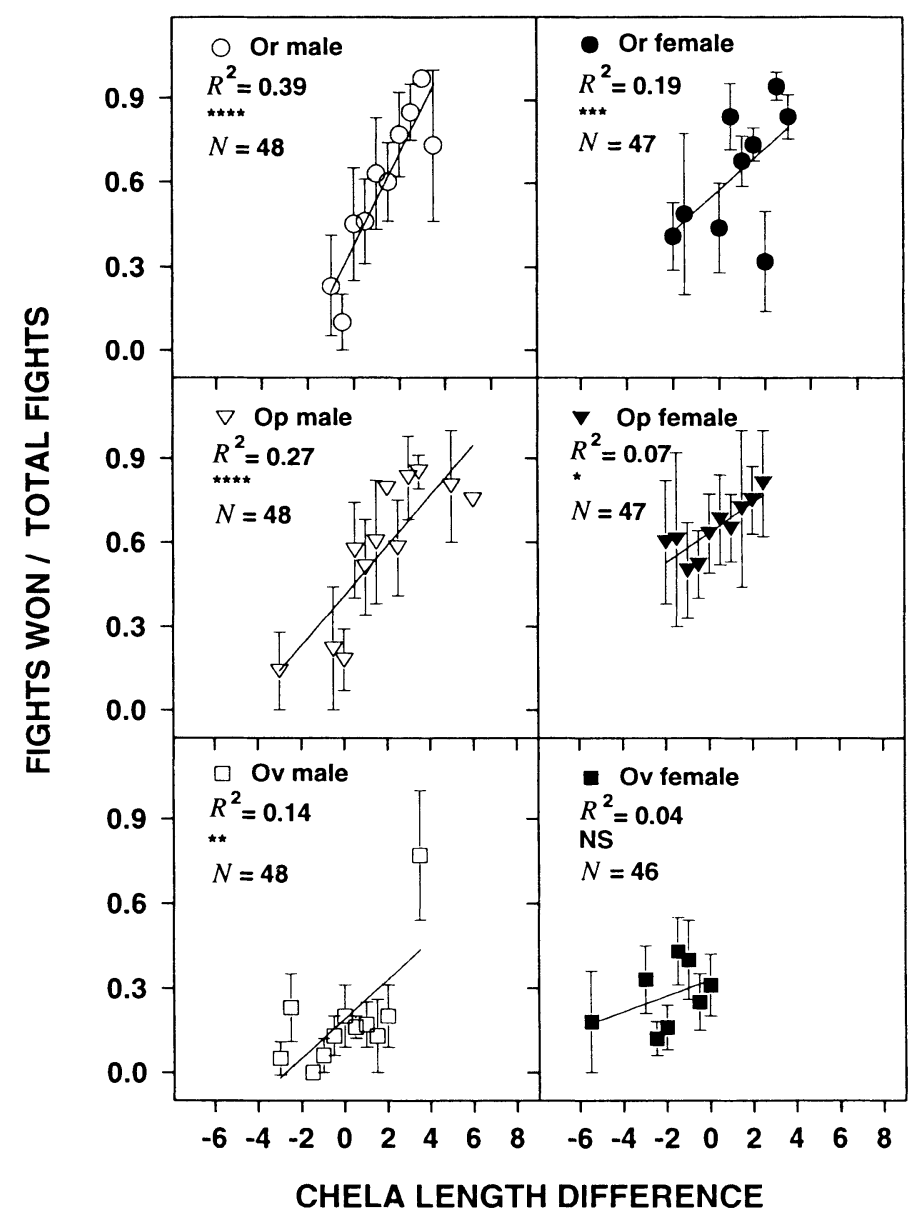

( $0.5 \mathrm{~mm}$ size classes)

FIG. 7. Effect of chela size differences ( $\pm 1 \mathrm{~mm}$ classes) on outcome of interspecific tension contacts during 1-h observations in 200-L aquaria. Six 20-mm CL crayfishes, two of each species, were used for each replicate treatment. Means are shown \pm 1 SE. Chela size difference trials consisting of only one fight were not plotted nor included in regression calculations. Regression models were analyzed using $F$ tests. NS $P>.05 ;{ }^{*} P \leq .05{ }^{* *} P<.01 ;{ }^{* * *} P<.001$.

resident fishes. Both invaders can replace the native crayfish $O$. virilis, despite its large size, as a result of interspecific interference competition and differential fish predator avoidance behavior. Although our results originate from laboratory and pool experiments, we believe they likely reflect interactions in the field. As in our experiments, rates of fish predation on crayfish in field-tethering experiments are quite high (Kershner 1992. Mather and Stein 1993, DiDonato and Lodge, in press) and in the field fish-crayfish interactions are frequent (J. E. Garvey, personal observation). In the following sections, we describe how our experiments provide insight into how predation and competition interact to influence crayfish replacements in northern Wisconsin lakes.

\section{Size-selective predation as a replacement mechanism}

In our experiments, similar-sized $O$. propinquus and O. rusticus did not differ substantially in susceptibility to fish predators or in aggressive and nonaggressive behaviors. However, natural size distributions, where $O$. rusticus can exceed $O$. propinquus by $>3 \mathrm{~mm}$ within each age class (Corey 1988), result in susceptibility and behavioral differences between these two species. Therefore, we hypothesize that small $O$. propinquus individuals are at a distinct disadvantage when sympatric with large $O$. rusticus owing to differential selection by fish predators and reduced competitive abilities.

Small decapod crustaceans including lobsters (Smith and Herrnkind 1992, Wahle and Steneck 1992) and crayfishes (Stein 1977, Butler and Stein 1985, Kershner 1992, Mather and Stein 1993, DiDonato and Lodge. in press) are more susceptible to fish predation than large counterparts. Indeed, small $O$. propinquus were consumed more frequently than the most recent invader $O$. rusticus. Because crayfish removal rates by fish predators can be high (especially on juveniles, Kershner 1992, Mather and Stein 1993, DiDonato and 
Lodge, in press). size-selective fish predation likely will reduce $O$. propinquus populations more quickly than sympatric $O$. rusticus populations.

Large crayfish are dominant over small crayfish. Large $O$. rusticus, likely via aggressive behavior, outcompete small $O$. propinquus for limited refuge. In turn, when crayfish densities become high (as they can in northern Wisconsin lakes reaching 60 individuals $/ \mathrm{m}^{2}$; Capelli 1975, Lorman 1980), relative to available refuges, their shelters can become limiting. In such situations, intense size-mediated shelter competition can lead to the exclusion of $O$. propinquus by competitively dominant O. rusticus.

We argue that both size-selective fish predation and perhaps interspecific competition underlie the replacement of $O$. propinquus by $O$. rusticus. Size-mediated fish predation and availability of shelter limits recruitment of juvenile lobsters to their adult life stage (Smith and Herrnkind 1992, Wahle and Steneck 1992). Similarly, when $O$. rusticus is present, small size and availability of shelter likely reduce recruitment of $O$. propinquus to subsequent age classes. In areas of sympatry, $O$. rusticus likely replaces $O$. propinquus.

\section{Crayfish interactions and behavior as replacement mechanisms}

Selective predation. $-O$. virilis was more susceptible to predation than similar-sized invaders on sand, macrophyte, and low density cobble substrates. These results agree with those of DiDonato and Lodge (in press), who tethered three size classes (15-18, 23-25, 33-35 $\mathrm{mm} \mathrm{CL}$ ) of all three species at six sand sites within Trout Lake. Like us, they found that $O$. virilis was selected over $O$. rusticus and $O$. propinquus. Their field verification of our pool and aquarium results confirms that $O$. virilis is at a distinct disadvantage when confronting predators.

On dense cobble substrates, differential susceptibility did not occur and predation rates were low. Not surprisingly, orconectid crayfish are abundant in such habitats (Stein 1977, Kershner 1992). However, in surveys of three macrophyte and three cobble sites in Trout Lake, $O$. virilis occurred exclusively in macrophyte habitats (J. Rettig, personal communication). Similarly, invaders displace similar-sized $O$. virilis from cobble substrates into macrophytes and sand (Hill and Lodge 1993). Therefore, whereas $O$. virilis may not be selected by fish predators in abundant cobble, invaders may force it into nonpreferred, high predatory-risk habitats. Such forced shifts in habitat-use of congeners by invaders have been observed in the Great Lakes (Crowder et al. 1981) and streams (Karp and Tyus 1990, DeWald and Wilzbach 1992), often to the exclusion of native species. In northern Wisconsin lakes, the native species $O$. virilis, excluded from dense cobble habitats by the two invaders, likely suffers greater predatory risk. Without access to a refuge from predators, $O$. virilis populations should be dramatically reduced.
As with differential habitat use, morphological differences among organisms influence susceptibility to predation (see Zaret 1980 for review). With crayfish, large chela size reduces vulnerability to fish by increasing capture and handling times (Stein 1977). Because the invaders possess larger chelae than O. virilis (Garvey and Stein 1993), we expected removal of chelae to eliminate differences in susceptibility. Surprisingly, however, chela size did not determine susceptibility; $O$. virilis was still more susceptible. We also predicted that differences in body size would influence differential selection. Although $O$. virilis grows larger than the invaders, potentially, it must exceed body size of the invaders by $4 \mathrm{~mm}$ just to attain equal susceptibility. Thus, although $O$. virilis is larger than the invaders, it is still selected by fish predators and eventually replaced. Below, we address characteristics unique to $O$. virilis that render it more vulnerable to fish predators than the invaders.

Interactions and behavior. - Factors such as differential coloration and palatability can influence vulnerability. Although such morphological characteristics are important, behavioral responses to predators also can contribute to abundance and distribution of a wide variety of organisms, including armored catfishes (Power 1984), shrimp (Main 1987), odonates (see Johnson 1991 for review), and crayfish (Stein and Magnuson 1976, Collins et al. 1983, Mather and Stein 1993). To understand crayfish behaviors that potentially influence susceptibility to predation, we quantified shelter competition, activity, predatory defense, swimming, and agonistic interactions. We then assessed whether $O$. virilis behaviors differed from those of its congeners, specifically exploring how these behaviors influenced vulnerability.

Risk of fish predation increases crayfish shelter use (Stein and Magnuson 1976, Stein 1977, Mather and Stein 1993). Without predatory risk, O. rusticus outcompetes both $O$. propinquus and $O$. virilis for shelters; in turn $O$. propinquus can displace $O$. virilis from shelters (Capelli and Munjal 1982). When unlimited shelters were combined with a fish predator, all three species used shelters, presumably to avoid predators. However, when limited shelters were combined with fish predators, $O$. virilis were inferior competitors for refuge. In the field where cobble is sparse, crayfish densities are high, and fish predators are present, $O$. virilis loses the battle for limited shelter and is replaced by the invaders.

Interestingly, $O$. virilis was selected over the invaders in limited and unlimited shelter experiments. In fact, more crayfish were consumed in unlimited shelter treatments. Conceivably, we did not detect a relationship between shelter availability and predatory susceptibility because we only quantified refuge use by rather crude, daily "snapshots" of shelter occupation. Likely, finer scale, unobserved interactions, such as fights over occupied shelters in limited or unlimited 
treatments, were important in determining vulnerability to predators (Sih et al. 1988). Indeed, in both pilot laboratory experiments (J. E. Garvey, unpublished data) and other shelter competition experiments (Capelli and Munjal 1982), O. rusticus and O. propinquus were observed to evict $O$. virilis from shelters. Because fish predators can easily capture an evicted swimming or exposed crayfish (Stein 1977, Mather and Stein 1993; J. E. Garvey, personal observation), $O$. virilis is at a competitive disadvantage when seeking either limited or unlimited shelters and therefore is vulnerable to predation. This may explain why, in low density cobble pools where shelters were still abundant for crayfish $(\approx 50$ rocks for 30 crayfish $), O$. virilis was still selected. An inability to successfully occupy shelters in the presence of invaders and fish predators, even when shelters are apparently unlimited, could clearly lead to the exclusion of the least aggressive species, $O$. virilis. In our view, predatory risk likely enhances aggressive, interference competition for refuge among crayfish congeners, thus increasing vulnerability to predation of the native species.

In addition to interactions at shelters, behavioral differences in response to congeners or predators influenced susceptibility. Often, susceptible prey may respond more to predatory risk than relatively invulnerable prey (Stein 1979, Sih 1984). For example, juvenile porcupines (Sweitzer and Berger 1992), sunfishes (Werner et al. 1983), lobsters (Smith and Herrnkind 1992, Wahle and Steneck 1992), and crayfish (Stein and Magnuson 1976) modify their behavior in response to predators more than their adult counterparts. Similarly, under predatory risk, individual $O$. virilis reduced activity more than invaders, possibly to avoid predator detection. However, crayfish congeners increased $O$. virilis activity when fish were present, likely through aggressive interactions. Because interspecific, rather than intraspecific, interactions occur more frequently for $O$. virilis, contact with invaders, rather than conspecifics, more likely compromised predator avoidance behavior by $O$. virilis and increased its vulnerability. Although chelac displays deter predators (Bovbjerg 1956, Stein and Magnuson 1976), O. virilis displayed chelae less than the invaders. $O$. virilis also participated in risky, lethal swim flights generated by interactions with predators or congeners. All these behaviors rendered $O$. virilis more susceptible to fish predators.

We conclude that $O$. rusticus and $O$. propinquus reduced their activity when threatened, yet continued to act aggressively via chelae displays toward predators. For the invaders, neither interactions with other crayfishes nor with fish predators caused risky behaviors. When alone, $O$. virilis reduced activity when confronting a largemouth bass and appeared to respond less aggressively than the invaders to it. In pool-tethering experiments, individual behavior alone was sufficient to render $O$. virilis more susceptible to predation. However, interspecific interactions, as well as predatory threat, increased the frequency of risky behaviors in $O$. virilis. In our view, $O$. virilis is adapted to systems where interactions with other crayfish and frequent encounters with fish predators are rare. Frequent encounters with invaders and with fish predators (given shelter eviction by invaders) increase $O$. virilis lethal behaviors which, in turn, contribute to its replacement.

Morphological differences such as coloration in fishes (Stacey and Chiszar 1975), size in pinnipeds (Bartholomew 1970), and plumage color in birds (Rhijn 1973 ) influence aggression. For crayfish, increased body and chela size reduce predatory susceptibility in two ways: (1) directly, by rendering fish consumption difficult and (2) indirectly, by increasing aggressive dominance, thus reducing risky behavior and ensuring shelter acquisition. Indirect effects of increasing body and chela size on aggression translated to susceptibility differences in $O$. virilis. For an individual $O$. virilis to overcome its morphological and behavioral disadvantages, it must be larger than its invaders. Indeed, 4- $\mathrm{mm}$ larger $O$. virilis, no longer forced into risky behavior and larger than the invaders (and therefore more difficult to handle), became equally vulnerable to largemouth bass predation. Although slightly larger in the field (Olsen et al. 1991), O. virilis must maintain such a size differential to avoid selection by predators. Interestingly, mean $O$. virilis $\mathrm{CL}$ increases in lakes as $O$. rusticus abundance increases (Olsen et al. 1991) reinforcing our interpretation. O. virilis, owing to its smaller chelae (Garvey and Stein 1993) and innate, low aggression (Capelli and Munjal 1982, this study), could not avoid selective consumption by predators, even with a slight size advantage. Therefore, in areas of sympatry with $O$. rusticus and $O$. propinquus, $O$. virilis is selected by fish predators and eventually replaced.

\section{CONCLUSIONS}

The ability of an introduced organism to establish and increase in numbers is difficult to predict (see Ehrlich 1986, Drake et al. 1989, Lodge 1993 for reviews). Both predation (Simberloff 1981, Robinson and Wellborn 1988) and competition (Crowell 1973. Levins and Heatwole 1973, Cole 1983, McLachlan 1985, Moulton and Pimm 1986) influence invasions. By assessing how an invading species replaces its congeners, we can begin to understand ecological mechanisms underlying community structure. In this study, we considered how predation and competition interact to modify crayfish species assemblages composed of invading and native species. For the O. rusticus-O. propinquus system, predation interacts directly with prey size to determine prey susceptibility, i.e., the smallest species, $O$. propinquus, suffers differential predation. Conversely, differences in size between $O$. propinquus and $O$. rusticus influence competition, which likely influences vulnerability. For the $O$. virilis-O. rusticus-O. propinquus system, predation interacts directly with prey behavior to determine predator choice. Conversely, prey interactions, modified by prey aggression, predatory re- 
sponse, and behaviors rather than size differences, influence susceptibility to fish predators. In both cases, fish predators modify prey relationships; interspecific interactions at one trophic level influence predator choice at another. Thus, we strongly suggest that both fish predation and prey competition are important, interrelated mechanisms that contribute to the replacement of $O$. propinquus and $O$. virilis by $O$. rusticus.

\section{ACKNOWLEDGMENTS}

We thank all University of Wisconsin, Trout Lake Station personnel for providing an ideal research environment in which to work. At the Aquatic Ecology Laboratory, spirited discussions and ample facilities were crucial to this work. We extend our appreciation to Jessica Rettig, Guy DiDonato, Anna Hill, Marty Horgan, and Doug Wojcieszak for technical help and suggestions. The advice of David Lodge and Libby Marschall was invaluable to this research. Comments on earlier drafts of this paper by Allison Snow, Tom Grubb, Mark Kershner, and two anonymous reviewers greatly improved the manuscript. Mr. Walt Haag, caretaker of Trout Lake Station, cannot be thanked enough for his support and technical wisdom. This project was supported through NSF grant BSR 8907691 to R. A. Stein in collaboration with David Lodge and Ken Brown. This paper is dedicated in memory of Dr. Robert W. Winner. His love for the outdoors, dry words of wisdom, and knowledge of applied ecology inspired much of this work.

\section{Literature CiTED}

Bartholomew, G. A. 1970. A model for the evolution of pinniped polygony. Evolution 24:546-559.

Berrill, M., and M. Arsenault. 1984. The breeding behavior of a north temperate orconectid crayfish, Orconectes rusticus. Animal Behavior 32:333-339.

Bovbjerg, R. V. 1953. Dominance order in the crayfish Orconectes virilis (Hagen). Physiological Zoology 26:173-178.

1956. Some factors affecting aggressive behavior in crayfish. Physiological Zoology 29:127-136.

1959. Density and dispersal in laboratory crayfish populations. Ecology 40:504-505.

Butler, M. J., IV, and R. A. Stein. 1985. An analysis of the mechanisms governing species replacements in crayfish. Oecologia 66:168-177.

Capelli, G. M. 1975. Distribution, life history, and ecology of crayfish in northern Wisconsin, with an emphasis on Orconectes propinquus (Girard). Dissertation. University of Wisconsin, Madison, Wisconsin, USA

- 1982. Displacement of northern Wisconsin crayfish by Orconectes rusticus (Girard). Limnology and Oceanography $27: 741-745$.

Capelli. G. M., and J. F. Capelli. 1980. Hybridization between crayfish of the genus Orconectes: morphological evidence (Decapoda, Cambaridae). Crustaceana 39:121-132.

Capelli, G. M., and B. M. Munjal. 1982. Aggressive interactions and resource competition in relation to species displacement among crayfish of the genus Orconectes. Journal of Crustacean Biology 2:486-492.

Cole, B. J. 1983. Assembly of mangrove ant communities: patterns of geographical distribution. Journal of Animal Ecology 52:339-347.

Collins, N. C., H. H. Harvey, A. J. Tierney, and D. W. Dunham. 1983. Influence of predator density on trapability of crayfish in Ontario lakes. Canadian Journal of Fisheries and Aquatic Sciences 40:1820-1828.

Corey, S. 1988. Comparative life histories of two populations of the introduced crayfish $O$. rusticus (Girard, 1852) in Ontario. Crustaceana 55:29-38.

Crowder, L. B., J. J. Magnuson, and S. B. Brandt. 1981.
Complementarity in the use of food and thermal habitat by Lake Michigan fishes. Canadian Journal of Fisheries and Aquatic Sciences 38:662-668.

Crowell, K. L. 1973. Experimental zoogeography: introductions of mice to small islands. American Naturalist 107: 535-558.

Cubit, J. D. 1984. Herbivory and the seasonal abundance of algae on a high rocky intertidal rocky shore. Ecology 65 : 1904-1917.

DeWald, L., and M. A. Wilzbach. 1992. Interactions between native brook trout and hatchery brown trout: effects on habitat use, feeding, and growth. Transactions of the American Fisheries Society 121:287-296.

DiDonato, G. T., and D. M. Lodge. In press. Species replacements among Orconectes species in Wisconsin lakes: the role of predation by fish. Canadian Journal of Fisheries and Aquatic Sciences.

Drake, J. A., H. A. Mooney, F. di Castri, R. H. Groves, F. J. Kruger, M. Rejmanek, and M. Williamson. 1989. Biological invasions: a global perspective. Scientific Committee on Problems of the Environment Report 37. Wiley, New York, New York, USA.

Ehrlich, P. R. 1986. Which animal will invade? Pages 79 95 in H. A. Mooney and J. A. Drake, editors. Ecology of biological invasions of North America and Hawaii. Springer-Verlag, New York, New York, USA.

Garvey, J. E., and R. A. Stein. 1993. Evaluating how chela size influences the invasion potential of an introduced crayfish. American Midland Naturalist 129:172-181.

Gliwicz, Z. M., and J. Pijanowska. 1989. The role of predation in zooplankton succession. Pages 253-296 in U. Sommer, editor. Plankton ecology, succession in planktonic communities. Springer-Verlag, New York, New York, USA.

Hairston, N. G., F. E. Smith, and L. B. Slobodkin. 1960. Community structure, population control, and competition. American Naturalist 94:421-425.

Hill, A. M., and D. M. Lodge. 1993. Competition for refugia in the face of predation risk: a mechanism for species replacement among ecologically similar crayfishes. Bulletin of the North American Benthological Society 10:120.

Huang, C., and A. Sih. 1990. Experimental studies on behaviorally mediated, indirect interactions through a shared predator. Ecology 71:1515-1522.

Huang, C., and A. Sih. 1991. Experimental studies on direct and indirect interactions in a three trophic-level stream system. Oecologia 85:530-536.

Hutchinson, G. E. 1959. Homage to Santa Rosalia or why are there so many kinds of animals? American Naturalist 93:145-159

Inouye, R. S., G. S. Byers, and J. H. Brown. 1980. Effects of predation and competition on survivorship, fecundity, and community structure of desert annuals. Ecology 61: 1344-1351

Johnson, D. M. 1991. Behavioral ecology of larval dragonflies and damselflies. Trends in Ecology and Evolution 6:8-12.

Johnson, D. M., P. H. Crowley, R. E. Bohanan, C. N. Watson, and T. H. Martin. 1985. Competition among larval dragonflies: a field enclosure experiment. Ecology 66:119-128.

Karp, C. A., and H. M. Tyus. 1990. Behavioral interactions between young Colorado squawfish and six fish species Copeia 1:25-34.

Kershner, M. W. 1992. The impact of landscape pattern on the invasion of northern Wisconsin lakes by the crayfish, Orconectes rusticus. Thesis. University of Notre Dame, Notre Dame, Indiana, USA.

Kotler, B. P., and R. D. Holt. 1989. Predation and competition: the interaction of two types of species interactions. Oikos 54:256-260.

Levins, R., and H. Heatwole. 1973. Biogeography of the 
Puerto Rican bank: introduction of species onto Palomintos Island. Ecology 54: 1056-1064.

Lodge. D. M. 1993. Species invasions and deletions: community effects and responses to climate and habitat change. Pages 367-387 in P. M. Kareiva, J. G. Kingsolver, and R. B. Huey, editors. Biotic interactions and global change. Sinauer, Sunderland, Massachusetts. USA.

Lodge, D. M.. T. K. Kratz, and G. M. Capelli. 1986. Longterm dynamics of three crayfish species in Trout Lake, Wisconsin. Canadian Journal of Fisheries and Aquatic Sciences 43:993-998.

Lorman. J. G. 1980. Ecology of the crayfish Orconectes rusticus in northern Wisconsin. Dissertation. University of Wisconsin. Madison. Wisconsin. USA

Lubchenco, J. 1978. Plant species diversity in a marine intertidal community: importance of herbivore food preference and algal competitive abilities. American Naturalist 112:23-39

MacArthur, R. H., and R. Levins. 1967. The limiting similarity, convergence and divergence of coexisting species. American Naturalist 101:377-385.

MacArthur, R. H., and E. R. Pianka. 1966. On optimal use of a patchy environment. American Naturalist 100:603609

Main, K. L. 1987. Predator avoidance in seagrass meadows: prey bchavior, microhabitat selection, and cryptic coloration. Ecology 68:170-180.

Mather, M. E., and R. A. Stein. 1993. Direct and indirect effects of fish predators on a crayfish species replacement. Canadian Journal of Fisheries and Aquatic Sciences 50: 1279-1288.

McLachlan, A. L. 1985. What determines species present in a rain-pool? Oikos $45: 1-7$.

McNecly, D. L., B. N. Futrell, and A. Sih. 1990. An experimental study on the effects of crayfish on the predatorprey interaction between bass and sculpin. Oecologia 85: $69-73$

Menge. B. A., and J. P. Sutherland. 1976. Species diversity gradients: synthesis of the roles of predation. competition. and environmental heterogencity. American Naturalist 110: $351-369$

Mittelbach. G. G. 1981. Foraging efficiency and body size: a study of optimal diet and habitat use by blucgills. Ecology 62:1370-1386.

Morin. P. J. 1981. Predatory salamanders reverse the outcome of competition among three species of anuran tadpoles. Science 212:1284-1286.

1984. The impact of fish exclusion on the abundance and species composition of larval odonates: results of shortterm experiments in a North Carolina farm pond. Ecology 65:53-60.

- 1986. Interactions between intraspecific competition and predation in an amphibian predator-prey system. Ecology 67:713-720.

Moulton. M. P.. and S. L. Pimm. 1986. The extent of competition in shaping an introduced avifauna. Pages 80-97 in J. Diamond and T. J. (ase, editors. Community ecology. Harper \& Row, New York. New York. USA

Olsen. T. M.. D. M. Lodge, G. M. Capelli, and R. J. Houlihan. 1991. Mechanisms of impact of an introduced crayfish (Orconectes rusticus) on littoral congeners, snails and macrophytes. Canadian Journal of Fisheries and Aquatic Sciences 48: 1853-1861.

Paine, R. T. 1966. Food web complexity and species diversity. American Naturalist 100:65-75.

Power, M. E. 1984. Depth distributions of armored catfish: predator-induced resource avoidance? Ecology 65:523-528.

Price. M. V. 1978. The role of microhabitat in structuring desert rodent communities. Ecology 59:910-921.

Quinn. J. P.. and J. Janssen. 1989. Crayfish competition in southwestern Lake Michigan: a predator mediated bottleneck. Journal of Freshwater Ecology 5:75-85.

Rhijn, J. G. 1973. Behavioural dimorphism in male ruffs. Philomachus pugnax (L.). Behaviour 47:153-229.

Robinson, J. V.. and G. A. Wellborn. 1988. Ecological resistance to the invasion of a freshwater clam, Corbicula fluminea: fish predation effects. Oecologia 77:445-452.

Saiki. M. K., and J. C. Tash. 1979. Use of cover and dispersal by crayfish to reduce predation by largemouth bass. Pages 44-48 in D. L. Johnson and R. A. Stein. editors Response of fish to habitat structure in standing water. American Fisheries Society, Special Publication 6.

Saiki, M. K., and C. D. Ziebell. 1976. Some trophic relationships of the largemouth bass. Micropterus salmoides (Lacepede) in a southwestern impoundment. Journal of the Arizona Academy of Science 11:99-104.

Schoener, T. W. 1983. Field experiments on interspecific competition. American Naturalist 122:240-285.

Sih. A. 1984. The behavioral response race between predator and prey. American Naturalist 123:143-150.

1987. Predators and prey lifestyles: an evolutionary and ecological overview. Pages 203-224 in W. C. Kerfoot and A. Sih, editors. Predation, direct and indirect impacts on aquatic communities. University Press of New England. Hanover. New Hampshire. USA.

Sih. A.. P. Crowley, M. McPeek. J. Petranka, and K. Strohmeier. 1985. Predation. competition, and prey communitics: a review of field experiments. Annual Review of Ecology and Systematics 16:269-311.

Sih. A.. J. W. Petranka. and L. B. Kats. 1988. The dynamics of prey refuge use: a model and tests with sunfish and salamanders. American Naturalist 132:463-483.

Simberloff, D. 1981. Community effects of introduced species. Pages 53-80 in M. H. Nitecki, editor. Biotic crises in ecological and evolutionary time. Academic Press. New York. New York. USA

Smith. D. W.. and S. D. Cooper. 1982. Competition among Cladocera. Ecology 63:1004-1015.

Smith, K. N., and W. F. Herrnkind. 1992. Predation on early juvenile spiny lobsters Panulirus argus (Latrielle): influence of size and shelter. Journal of Experimental Marine Biology and Ecology 157:3-18.

Söderbäck. B. 1990. Interspecific dominance relationship and aggressive interactions in the freshwater crayfishes $4 \mathrm{~s}$ tacus Astacus (L.) and Pacifasticus leniusculus (Dana). Canadian Journal of Zoology 69:1321-1325.

Sokal. R. R.. and F. J. Rohlf. 1981. Biometry: the principles and practice of statistics in biological research. W. H. Freeman. New York. New York. USA.

Southerland, M. D. 1986. Coexistence of three congeneric salamanders: the importance of habitat and body size. Ecology 67:721-728.

Stacey, P. B.. and D. Chiszar. 1975. Changes in the darkness of four body features of bluegill sunfish (Lepomis macro(hirus Rafinesque) during aggressive encounters. Behavioral Biology 14:41-49.

Stein. R. A. 1977. Selective predation, optimal foraging. and the predator-prey interaction between fish and crayfish Ecology 58:1237-1253

- 1979. Behavioral response of prey to fish predators. Pages 343-353 in R. H. Stroud and H. Clepper, editors. Predator-prey systems in fisheries management. Sport Fishing Institute, Washington, D.C., USA.

Stein. R. A., and J. J. Magnuson. 1976. Behavioral response of a crayfish to a fish predator. Ecology 57:751-761.

Steneck, R. S. S. D. Hacker, and M. N. Dethier. 1991 Mechanisms of competitive dominance between crustose coralline algae: an herbivore-mediated competitive reversal. Ecology 72:938-950.

Sweitzer, R. A., and J. Berger. 1992. Size-related effects of 
predation on habitat use and behavior of porcupines ( $\mathrm{Er}$ (thizon dorsatum). Ecology 73:867-875.

Wahle, R. A., and R. S. Steneck. 1992. Habitat restrictions in early benthic life: experiments on habitat selection and in situ predation with the American lobster. Journal of Experimental Marine Biology and Ecology 157:91-114.

Werner, E. E., J. F. Gilliam, D. J. Hall, and G. G. Mittelbach. 1983. An experimental test of the effects of predation risk on habitat use in fish. Ecology 64: 1540-1548.
Wilbur, H. M.. P. J. Morin, and R. H. Harris. 1983. Salamander predation and the structure of experimental communities: anuran responses. Ecology 64:1423-1429.

Wilkinson, L. 1990. SYSTAT: the system for statistics. SYSTAT, Evanston, Illinois, USA.

Zaret. T. M. 1980. Predation and freshwater communities. Edward Brothers, Ann Arbor, Michigan, USA. 
http://www.jstor.org

\title{
LINKED CITATIONS
}

\author{
- Page 1 of 7 -
}

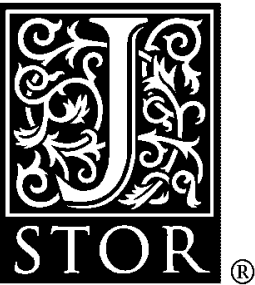

You have printed the following article:

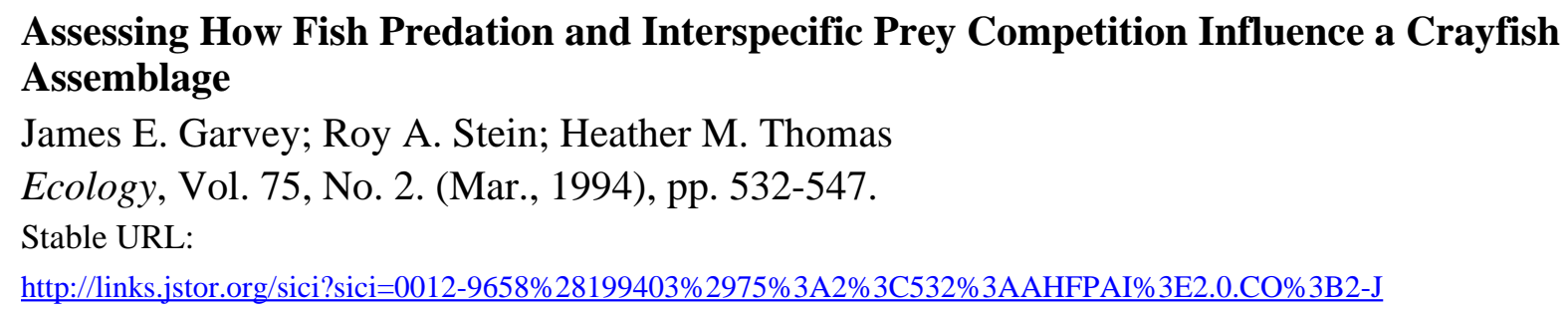

Assessing How Fish Predation and Interspecific Prey Competition Influence a Crayfish Assemblage

James E. Garvey; Roy A. Stein; Heather M. Thomas

Ecology, Vol. 75, No. 2. (Mar., 1994), pp. 532-547.

Stable URL:

http://links.jstor.org/sici?sici=0012-9658\%28199403\%2975\%3A2\%3C532\%3AAHFPAI\%3E2.0.CO\%3B2-J

This article references the following linked citations. If you are trying to access articles from an off-campus location, you may be required to first logon via your library web site to access JSTOR. Please visit your library's website or contact a librarian to learn about options for remote access to JSTOR.

\section{Literature Cited}

\author{
A Model for the Evolution of Pinniped Polygyny \\ George A. Bartholomew \\ Evolution, Vol. 24, No. 3. (Sep., 1970), pp. 546-559. \\ Stable URL: \\ http://links.jstor.org/sici?sici=0014-3820\%28197009\%2924\%3A3\%3C546\%3AAMFTEO\%3E2.0.CO\%3B2-1

\section{Density and Dispersal in Laboratory Crayfish Populations} \\ Richard V. Bovbjerg \\ Ecology, Vol. 40, No. 3. (Jul., 1959), pp. 504-506. \\ Stable URL: \\ http://links.jstor.org/sici?sici=0012-9658\%28195907\%2940\%3A3\%3C504\%3ADADILC\%3E2.0.CO\%3B2-R
}

\author{
Displacement of Northern Wisconsin Crayfish by Orconectes rusticus (Girard) \\ Gregory M. Capelli \\ Limnology and Oceanography, Vol. 27, No. 4. (Jul., 1982), pp. 741-745. \\ Stable URL: \\ http://links.jstor.org/sici?sici=0024-3590\%28198207\%2927\%3A4\%3C741\%3ADONWCB\%3E2.0.CO\%3B2-W
}


http://www.jstor.org

\section{LINKED CITATIONS}

- Page 2 of 7 -

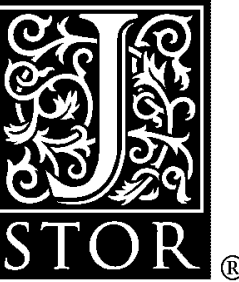

Aggressive Interactions and Resource Competition in Relation to Species Displacement among Crayfish of the Genus Orconectes

Gregory M. Capelli; Barbara L. Munjal

Journal of Crustacean Biology, Vol. 2, No. 4. (Nov., 1982), pp. 486-492.

Stable URL:

http://links.jstor.org/sici?sici=0278-0372\%28198211\%292\%3A4\%3C486\%3AAIARCI\%3E2.0.CO\%3B2-8

Assembly of Mangrove Ant Communities: Patterns of Geographical Distribution

Blaine J. Cole

The Journal of Animal Ecology, Vol. 52, No. 2. (Jun., 1983), pp. 339-347.

Stable URL:

http://links.jstor.org/sici?sici=0021-8790\%28198306\%2952\%3A2\%3C339\%3AAOMACP\%3E2.0.CO\%3B2-C

Experimental Zoogeography: Introductions of Mice to Small Islands

Kenneth L. Crowell

The American Naturalist, Vol. 107, No. 956. (Jul. - Aug., 1973), pp. 535-558.

Stable URL:

http://links.jstor.org/sici?sici=0003-0147\%28197307\%2F08\%29107\%3A956\%3C535\%3AEZIOMT\%3E2.0.CO\%3B2-\%23

Herbivory and the Seasonal Abundance of Algae on a High Intertidal Rocky Shore

John D. Cubit

Ecology, Vol. 65, No. 6. (Dec., 1984), pp. 1904-1917.

Stable URL:

http://links.jstor.org/sici?sici=0012-9658\%28198412\%2965\%3A6\%3C1904\%3AHATSAO\%3E2.0.CO\%3B2-V

Evaluating How Chela Size Influences the Invasion Potential of an Introduced Crayfish (Orconectes rusticus)

James E. Garvey; Roy A. Stein

American Midland Naturalist, Vol. 129, No. 1. (Jan., 1993), pp. 172-181.

Stable URL:

http://links.jstor.org/sici?sici=0003-0031\%28199301\%29129\%3A1\%3C172\%3AEHCSIT\%3E2.0.CO\%3B2-5

Community Structure, Population Control, and Competition

Nelson G. Hairston; Frederick E. Smith; Lawrence B. Slobodkin

The American Naturalist, Vol. 94, No. 879. (Nov. - Dec., 1960), pp. 421-425.

Stable URL:

http://links.jstor.org/sici?sici=0003-0147\%28196011\%2F12\%2994\%3A879\%3C421\%3ACSPCAC\%3E2.0.CO\%3B2-A 
http://www.jstor.org

\section{LINKED CITATIONS}

- Page 3 of 7 -

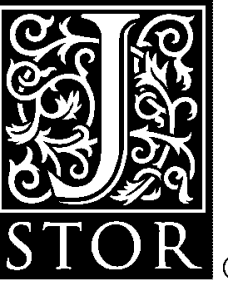

Experimental Studies on Behaviorally Mediated, Indirect Interactions through a Shared Predator

Chifu Huang; Andrew Sih

Ecology, Vol. 71, No. 4. (Aug., 1990), pp. 1515-1522.

Stable URL:

http://links.jstor.org/sici?sici=0012-9658\%28199008\%2971\%3A4\%3C1515\%3AESOBMI\%3E2.0.CO\%3B2-K

Homage to Santa Rosalia or Why Are There So Many Kinds of Animals?

G. E. Hutchinson

The American Naturalist, Vol. 93, No. 870. (May - Jun., 1959), pp. 145-159.

Stable URL:

http://links.jstor.org/sici?sici=0003-0147\%28195905\%2F06\%2993\%3A870\%3C145\%3AHTSROW\%3E2.0.CO\%3B2-D

Effects of Predation and Competition on Survivorship, Fecundity, and Community Structure of Desert Annuals

Richard S. Inouye; Gregory S. Byers; James H. Brown

Ecology, Vol. 61, No. 6. (Dec., 1980), pp. 1344-1351.

Stable URL:

http://links.jstor.org/sici?sici=0012-9658\%28198012\%2961\%3A6\%3C1344\%3AEOPACO\%3E2.0.CO\%3B2-L

\section{Competition among Larval Dragonflies: A Field Enclosure Experiment}

Dan M. Johnson; Philip H. Crowley; Robert E. Bohanan; Charles N. Watson; Thomas H. Martin Ecology, Vol. 66, No. 1. (Feb., 1985), pp. 119-128.

Stable URL:

http://links.jstor.org/sici?sici=0012-9658\%28198502\%2966\%3A1\%3C119\%3ACALDAF\%3E2.0.CO\%3B2-A

Behavioral Interactions between Young Colorado Squawfish and Six Fish Species

Catherine A. Karp; Harold M. Tyus

Copeia, Vol. 1990, No. 1. (Mar. 6, 1990), pp. 25-34.

Stable URL:

http://links.jstor.org/sici?sici=0045-8511\%2819900306\%293\%3A1990\%3A1\%3C25\%3ABIBYCS\%3E2.0.CO\%3B2-H

Biogeography of the Puerto Rican Bank: Introduction of Species onto Palominitos Island

Richard Levins; Harold Heatwole

Ecology, Vol. 54, No. 5. (Sep., 1973), pp. 1056-1064.

Stable URL:

http://links.jstor.org/sici?sici=0012-9658\%28197309\%2954\%3A5\%3C1056\%3ABOTPRB\%3E2.0.CO\%3B2-P 
http://www.jstor.org

\section{LINKED CITATIONS}

- Page 4 of 7 -

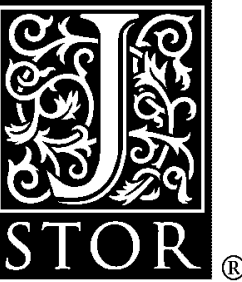

The Limiting Similarity, Convergence, and Divergence of Coexisting Species

Robert Macarthur; Richard Levins

The American Naturalist, Vol. 101, No. 921. (Sep. - Oct., 1967), pp. 377-385.

Stable URL:

http://links.jstor.org/sici?sici=0003-0147\%28196709\%2F10\%29101\%3A921\%3C377\%3ATLSCAD\%3E2.0.CO\%3B2-Y

On Optimal Use of a Patchy Environment

Robert H. MacArthur; Eric R. Pianka

The American Naturalist, Vol. 100, No. 916. (Nov. - Dec., 1966), pp. 603-609.

Stable URL:

http://links.jstor.org/sici?sici=0003-0147\%28196611\%2F12\%29100\%3A916\%3C603\%3AOOUOAP\%3E2.0.CO\%3B2-1

Predator Avoidance in Seagrass Meadows: Prey Behavior, Microhabitat Selection, and Cryptic Coloration

Kevan L. Main

Ecology, Vol. 68, No. 1. (Feb., 1987), pp. 170-180.

Stable URL:

http://links.jstor.org/sici?sici=0012-9658\%28198702\%2968\%3A1\%3C170\%3APAISMP\%3E2.0.CO\%3B2-7

Species Diversity Gradients: Synthesis of the Roles of Predation, Competition, and Temporal Heterogeneity

Bruce A. Menge; John P. Sutherland

The American Naturalist, Vol. 110, No. 973. (May - Jun., 1976), pp. 351-369.

Stable URL:

http://links.jstor.org/sici?sici=0003-0147\%28197605\%2F06\%29110\%3A973\%3C351\%3ASDGSOT\%3E2.0.CO\%3B2-2

Foraging Efficiency and Body Size: A Study of Optimal Diet and Habitat Use by Bluegills

Gary G. Mittelbach

Ecology, Vol. 62, No. 5. (Oct., 1981), pp. 1370-1386.

Stable URL:

http://links.jstor.org/sici?sici=0012-9658\%28198110\%2962\%3A5\%3C1370\%3AFEABSA\%3E2.0.CO\%3B2-A

Predatory Salamanders Reverse the Outcome of Competition among Three Species of Anuran Tadpoles

Peter J. Morin

Science, New Series, Vol. 212, No. 4500. (Jun. 12, 1981), pp. 1284-1286.

Stable URL:

http://links.jstor.org/sici?sici=0036-8075\%2819810612\%293\%3A212\%3A4500\%3C1284\%3APSRTOO\%3E2.0.CO\%3B2-2 
http://www.jstor.org

\section{LINKED CITATIONS}

- Page 5 of 7 -

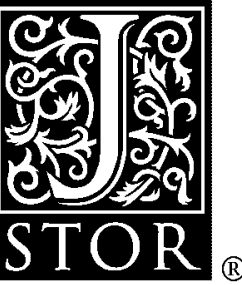

The Impact of Fish Exclusion on the Abundance and Species Composition of Larval Odonates: Results of Short-Term Experiments in a North Carolina Farm Pond

Peter J. Morin

Ecology, Vol. 65, No. 1. (Feb., 1984), pp. 53-60.

Stable URL:

http://links.jstor.org/sici?sici=0012-9658\%28198402\%2965\%3A1\%3C53\%3ATIOFEO\%3E2.0.CO\%3B2-E

Interactions Between Intraspecific Competition and Predation in an Amphibian Predator-Prey System

Peter Jay Morin

Ecology, Vol. 67, No. 3. (Jun., 1986), pp. 713-720.

Stable URL:

http://links.jstor.org/sici?sici=0012-9658\%28198606\%2967\%3A3\%3C713\%3AIBICAP\%3E2.0.CO\%3B2-X

Food Web Complexity and Species Diversity

Robert T. Paine

The American Naturalist, Vol. 100, No. 910. (Jan. - Feb., 1966), pp. 65-75.

Stable URL:

http://links.jstor.org/sici?sici=0003-0147\%28196601\%2F02\%29100\%3A910\%3C65\%3AFWCASD\%3E2.0.CO\%3B2-D

Depth Distributions of Armored Catfish: Predator-Induced Resource Avoidance?

Mary E. Power

Ecology, Vol. 65, No. 2. (Apr., 1984), pp. 523-528.

Stable URL:

http://links.jstor.org/sici?sici=0012-9658\%28198404\%2965\%3A2\%3C523\%3ADDOACP\%3E2.0.CO\%3B2-7

The Role of Microhabitat in Structuring Desert Rodent Communities

Mary V. Price

Ecology, Vol. 59, No. 5. (Late Summer, 1978), pp. 910-921.

Stable URL:

http://links.jstor.org/sici?sici=0012-9658\%28197822\%2959\%3A5\%3C910\%3ATROMIS\%3E2.0.CO\%3B2-0

Field Experiments on Interspecific Competition

Thomas W. Schoener

The American Naturalist, Vol. 122, No. 2. (Aug., 1983), pp. 240-285.

Stable URL:

http://links.jstor.org/sici?sici=0003-0147\%28198308\%29122\%3A2\%3C240\%3AFEOIC\%3E2.0.CO\%3B2-9 
http://www.jstor.org

\section{LINKED CITATIONS}

- Page 6 of 7 -

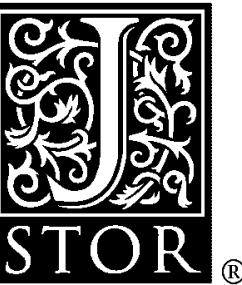

The Behavioral Response Race Between Predator and Prey

Andrew Sih

The American Naturalist, Vol. 123, No. 1. (Jan., 1984), pp. 143-150.

Stable URL:

http://links.jstor.org/sici?sici=0003-0147\%28198401\%29123\%3A1\%3C143\%3ATBRRBP\%3E2.0.CO\%3B2-9

Predation, Competition, and Prey Communities: A Review of Field Experiments

Andrew Sih; Philip Crowley; Mark McPeek; James Petranka; Kevin Strohmeier

Annual Review of Ecology and Systematics, Vol. 16. (1985), pp. 269-311.

Stable URL:

http://links.jstor.org/sici?sici=0066-4162\%281985\%2916\%3C269\%3APCAPCA\%3E2.0.CO\%3B2-P

The Dynamics of Prey Refuge Use: A Model and Tests with Sunfish and Salamander Larvae Andrew Sih; James W. Petranka; Lee B. Kats

The American Naturalist, Vol. 132, No. 4. (Oct., 1988), pp. 463-483.

Stable URL:

http://links.jstor.org/sici?sici=0003-0147\%28198810\%29132\%3A4\%3C463\%3ATDOPRU\%3E2.0.CO\%3B2-Z

\section{Competition Among Cladocera}

Daniel Wilkins Smith; Scott D. Cooper

Ecology, Vol. 63, No. 4. (Aug., 1982), pp. 1004-1015.

Stable URL:

http://links.jstor.org/sici?sici=0012-9658\%28198208\%2963\%3A4\%3C1004\%3ACAC\%3E2.0.CO\%3B2-0

Coexistence of Three Congeneric Salamanders: The Importance of Habitat and Body Size Mark T. Southerland

Ecology, Vol. 67, No. 3. (Jun., 1986), pp. 721-728.

Stable URL:

http://links.jstor.org//sici?sici=0012-9658\%28198606\%2967\%3A3\%3C721\%3ACOTCST\%3E2.0.CO\%3B2-W

Selective Predation, Optimal Foraging, and the Predator-Prey Interaction Between Fish and Crayfish

Roy A. Stein

Ecology, Vol. 58, No. 6. (Nov., 1977), pp. 1237-1253.

Stable URL:

http://links.jstor.org/sici?sici=0012-9658\%28197711\%2958\%3A6\%3C1237\%3ASPOFAT\%3E2.0.CO\%3B2-T 
http://www.jstor.org

\section{LINKED CITATIONS \\ - Page 7 of 7 -}

Behavioral Response of Crayfish to a Fish Predator

Roy A. Stein; John J. Magnuson

Ecology, Vol. 57, No. 4. (Jul., 1976), pp. 751-761.

Stable URL:

http://links.jstor.org/sici?sici=0012-9658\%28197607\%2957\%3A4\%3C751\%3ABROCTA\%3E2.0.CO\%3B2-2

Mechanisms of Competitive Dominance Between Crustose Coralline Algae: An Herbivore-Mediated Competitive Reversal

Robert S. Steneck; Sally D. Hacker; Megan N. Dethier

Ecology, Vol. 72, No. 3. (Jun., 1991), pp. 938-950.

Stable URL:

http://links.jstor.org/sici?sici=0012-9658\%28199106\%2972\%3A3\%3C938\%3AMOCDBC\%3E2.0.CO\%3B2-Y

Size-Related Effects of Predation on Habitat Use and Behavior of Porcupines (Erethizon Dorsatum)

Richard Alan Sweitzer; Joel Berger

Ecology, Vol. 73, No. 3. (Jun., 1992), pp. 867-875.

Stable URL:

http://links.jstor.org/sici?sici=0012-9658\%28199206\%2973\%3A3\%3C867\%3ASEOPOH\%3E2.0.CO\%3B2-8

An Experimental Test of the Effects of Predation Risk on Habitat Use in Fish

Earl E. Werner; James F. Gilliam; Donald J. Hall; Gary G. Mittelbach

Ecology, Vol. 64, No. 6. (Dec., 1983), pp. 1540-1548.

Stable URL:

http://links.jstor.org/sici?sici=0012-9658\%28198312\%2964\%3A6\%3C1540\%3AAETOTE\%3E2.0.CO\%3B2-C

Salamander Predation and the Structure of Experimental Communities: Anuran Responses Henry M. Wilbur; Peter J. Morin; Reid N. Harris

Ecology, Vol. 64, No. 6. (Dec., 1983), pp. 1423-1429.

Stable URL:

http://links.jstor.org/sici?sici=0012-9658\%28198312\%2964\%3A6\%3C1423\%3ASPATSO\%3E2.0.CO\%3B2-E 